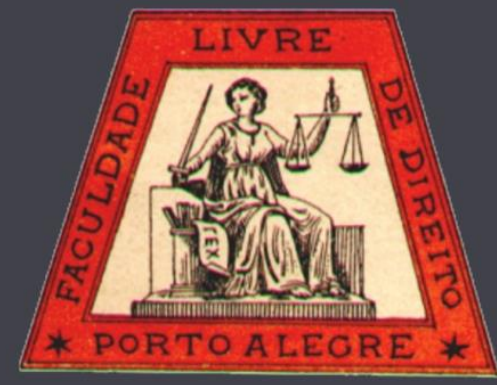

\title{
Os princípios retores da organização estatal nas Índias
}

The guiding principles of the state organization in the Indies

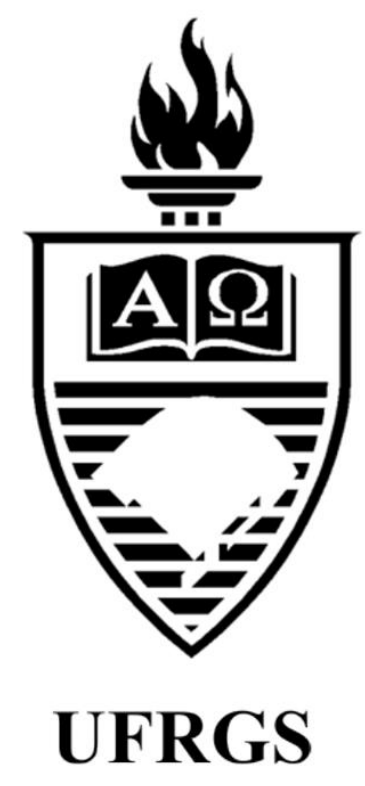

\author{
Horst Pietschmann
}

Universidade de Hamburgo

Revista da Faculdade de Direito da UFRGS

ISSN: 0104-6594 Site http://seer.ufrgs.br/revfacdir

Faculdade de Direito da UFRGS - Rua Riachuelo, 1317 - Centro - Porto Alegre - RS - Brasil

CEP - 90010-271 - Telefone: +55 5133083118 - Site http://www.ufrgs.br/direito/ 


\title{
Os princípios retores da organização estatal nas Índias*
}

\author{
The guiding principles of the state organization in the Indies
}

Horst Pietschmann ${ }^{* *}$

\author{
REFERÊNCIA \\ PIETSCHMANN, Horst. Os princípios retores da organização estatal nas Índias. Revista da Faculdade de Direito da \\ UFRGS, Porto Alegre, n. 35, p. 24-58, dez. 2016.
}

\section{RESUMO}

Na América hispânica, as regiões começam a se articular mais em virtude do dinamismo da economia, das concentrações demográficas, institucionais e de poder e de outros fatores geopolíticos. As novas articulações do espaço colonial apenas parcialmente e, quando fosse o caso, respondiam às estruturas governamentais do aparato imperial estabelecido durante o século XVI. Ao mesmo tempo, dá-se um processo inverso: por diferentes causas sejam geopolíticas, econômicas etc. - determinadas regiões, dotadas, inclusive, de aparato burocrático próprio, entram na órbita de centros mais poderosos que conseguem impor política e economicamente sua autoridade e poder. Esse conjunto de desenvolvimentos contraditórios, que até o momento só se estudou parcialmente na dimensão econômica, porém muito pouco na político-administrativa, em realidade é o início do processo que denominamos de fase de formação de proto-Estados. As reformas do século XVIII são, em grande media, a consequência ou a resposta tardia a desenvolvimentos prévios que se produziram mais bem contra a vontade da metrópole, em momentos de debilidade da Coroa, frente ao processo de desarticulação imperial que ocorre não só na América, mas também nas possessões europeias. É precisamente a perspectiva global do Império hispânico para a segunda metade do século XVII que permite caracterizar esse processo de desintegração imperial como um processo de surgimento de novas entidades políticas que adquirem um maior grau de autonomia e influíram na formação de novos Estados independentes.

\section{PALAVRAS-CHAVE}

História da América Hispânica. Formação de Estados. Organização estatal. Império Hispânico.

\begin{abstract}
In Hispanic America, the regions have begun to articulate more by virtue of economic dynamism, demographic, institutional and power concentrations, and other geopolitical factors. The new articulations of the colonial space only partially, and when was the case, responded to the governmental structures of the imperial apparatus established during the 16th century. At the same time, there is an inverse process: for different causes - geopolitical, economic, etc. - certain regions, even equipped with their own bureaucratic apparatus, enter into the orbit of more powerful centers that can politically and economically impose their authority and power. This set of contradictory developments, which until now has been studied only partially in the economic dimension, but very little in the political-administrative sphere, is actually the beginning of the process we call the proto-state formation phase. The reforms of the 18th century are, in large measure, the consequence or the late answer to previous developments that have been produced against the will of the metropolis, in moments of weakness of the Crown, during the process of imperial disarticulation that occurs not only in America, but also in European possessions. It is precisely the global perspective of the Spanish Empire during the second half of the 17th century that allows us to characterize this process of imperial disintegration as a process of emergence of new political entities that acquire a greater degree of autonomy and influenced the formation of new independent states.
\end{abstract}

\section{KEYWORDS}

History of Hispanic America. State formation. State organization. Spanish Empire.

\section{SUMÁRIO}

\footnotetext{
* Texto original publicado em língua espanhola - PIETSCHMANN, Horst. Los principios rectores de organización estatal en las Indias. In: ANNINO, Antonio; GUERRA, François-Xavier (coord.). Inventando la nación: Iberoamérica, siglo XIX. México: Fondo de Cultura Económica, 2003. p. 47-84. Tradução para língua portuguesa de Henrique Montagner Fernandes (PPGDir-UFRGS). Revisão da tradução por Alfredo de J. Flores (PPGDir-UFRGS).

${ }^{* *}$ Professor emérito da Universidade de Hamburgo.
} 
1. Historiografia, métodos e conceitos. 2.As origens dos futuros Estados. 3. Burocracia imperial e sociedade criolla. 4. Periodização. 5. Modelos de organização política.

\section{HISTORIOGRAFIA, MÉTODOS CONCEITOS}

A historiografia sobre a organização estatal na América hispânica colonial tem uma extensa trajetória. Sem que se queira aspirar a que a seguinte enumeração seja completa ${ }^{1}$, autores como Enrique Ruíz Guiñazú, Lillian Estelle Fisher, Rafael Altamira, Silvio Zavala, José M. Ots Capdequí, Alfonso García Gallo, José Miranda, Ricardo Zorraquín Becú, Juan Manzano Manzano, Jorge Ignacio Rubio Mañé, Mario Góngora e Guillermo Lohmann Villena produziram obras fundamentais sobre o tema, até fins da década de cinquenta do século XX. Convém recordar esses clássicos do tema porque representam um enfoque importante sobre um problema que ainda na atualidade tem seus cultores, mesmo que essa linha de investigação tenha sido, em grande medida, substituída por outras com muito maior êxito na atualidade. Aqueles clássicos, apesar de terem trabalhado sobre distintos níveis da administração colonial, compartilhavam, em certa medida, uma perspectiva e um enfoque metodológico comum. A perspectiva era, com maior ou menor clareza, a
E do Império colonial espanhol, isto é, que sua articulação em distintos níveis administrativos na América era observada a partir da perspectiva metropolitana. O método empregado era, em linhas gerais, o histórico-jurídico-institucional, que consistia em analisar a ampla legislação metropolitana - sobretudo a vice-real - com a intenção de reconstruir o que se acreditava que era a realidade do Império americano. Tomando por base esta bibliografia, surgiram, durante os anos sessenta, algumas obras gerais que pretendiam resumir a constituição interna do Império a partir de uma perspectiva histórica mais ampla, frequentemente empregando conceitos $\mathrm{e}$ aproximações de interpretação procedentes das ciências sociais ${ }^{2}$.

Paralelamente, a Escola dos Annales na França e a historiografia anglo-saxã começaram a reorientar a investigação sobre a época colonial hispano-americana para os problemas econômico-sociais regionais. Esta adquiriu um forte enfoque quantitativo, ainda que mantivesse majoritariamente ainda a perspectiva imperial, se bem que as fontes agora proviessem em grande parte dos arquivos nacionais, regionais e locais dos distintos países latino-americanos ${ }^{3}$. Ao

\footnotetext{
${ }^{1}$ Para não transbordar em títulos e citações, faço remissão, para além das obras geralmente conhecidas, aos trabalhos que se referem à época colonial no volume VÁZQUEZ DE PRADA VALLEJO, Valentín; OLÀBARRI GORTÁZAR, Ignacio. (Org.). Balance de la historiografía sobre Iberoamérica. Actas de las IV Conversaciones Internacionales de Historia. Centro de Investigaciones de Historia Moderna y Contemporánea, Universidad de Navarra, Pamplona, 10-12 marzo 1988. Pamplona, 1989. Também conferir meu manual: PIETSCHMANN, Horst. Die staatliche Organisation des kolonialen Iberoamerika. Stuttgart, 1980. Os principais trabalhos dos autores mencionados estão recolhidos em ambas as obras. Posteriormente, foram publicadas duas compilações importantes da obra dispersa de Alfonso García Gallo e de Ricardo Zorraquín Becú: GARCÍA GALLO, Alfonso. Los orígenes españoles de las instituciones americanas: estudios de derecho indiano. Madrid, 1987; ZORRAQUÍN BECÚ, Ricardo. Estudios de historia del derecho. 3 vols. Buenos Aires, 1988-1992. ${ }^{2}$ SARFATTI, Magali. Spanish Bureaucratic Patrimonialism in America. Politics of Modernization Series, n. 1, Institute of International Studies. Berkeley: University of California Press, 1966. EISENSTADT, S. N. The Political Systems of Empires. New York: The Free Press of Glencoe, 1963. PHELAN, J. L. The Kingdom of Quito in the Seventeenth Century. Bureaucratic Politics in the Spanish Empire. Madison: The University of Wisconsin Press, 1967.

${ }^{3}$ Cf. as obras clássicas de CHAUNU, Pierre; CHAUNU, Huguette. Séville et l'Atlantique, 1504-1650. 8 tomos em 11 volumes. Paris, 1955-1958. CHEVALIER, François. La formation de grands domaines au Mexique: terre et sociètè aux $X V I^{e}-X V I I^{e}$ siècles. Para a historiografia anglo-saxã há que remeter em primeiro lugar às obras de Woodrow Borah, Sherburne F. Cook e Lesley B. Simpson sobre demografia histórica, comércio etc. Cf., em especial, BORAH, Woodrow.
} 
mesmo tempo, historiadores mais jovens, que em maior ou menor medida estavam vinculados com a tradição anterior, lançaram-se a estudar os fenômenos da venda ou do benefício dos cargos administrativos na América, com o qual se iniciou a relacionar o tema do Estado com a sociedade. $\mathrm{O}$ tema do Estado começou a ser revisitado de novo em princípios dos anos oitenta, embora agora não se centrasse tanto no institucional, mas antes desde a perspectiva da engrenagem entre os fenômenos econômico-sociais e os institucionais, e insistindo mais nos aspectos políticos que resultavam desse complexo jogo de relações ${ }^{4}$.

Entretanto, a maioria dos estudos econômico-sociais foi abandonando a perspectiva imperial e, após ter detectado enormes variantes regionais no desenvolvimento histórico do continente, interessaram-se cada vez mais pelo seu significado político, interpretando-as como expressões da necessidade crescente do Império de unir regiões e centrá-las em torno à metrópole. A partir dessa perspectiva, levantava-se a dúvida de até que ponto as novas articulações políticas eram expressão de novas identidades históricas e de como estas prefiguravam, de certa maneira, os Estados independentes que surgiriam a partir das guerras de emancipação no Império espanhol. Seria possível perguntar-se até que ponto o desenvolvimento dessas diferenciações regionais era parte de um processo de formação estatal

Early Colonial Trade and Navigation between Mexico and Peru. Berkeley, 1954. New Spain's Century of Depression. Berkeley, 1951. Silk Raising in Colonial Mexico. Berkeley, 1943.___ COOK, Sherbume F. Price Trends of Some Basic Commodities in Central Mexico, 1531-1570, para mencionar só alguns títulos. A eles se somaram, posteriormente, autores como BRADING, David A. Miners and Merchants in Bourbon Mexico, 17631810. Cambridge, 1971. BAKEWELL, Peter J. Silver Mining and Society in Colonial Mexico, Zacatecas, 15461700. Cambridge, 1971. HAMNETT, Brian R. Politics and Trade in Southern México, 1750-1821. Cambridge, 1971; e muitos outros. O interesse nos aspectos políticoinstitucionais diminuiu na jovem geração anglo-saxã, assim como no novo enfoque francês.

${ }^{4}$ Como exemplo, os dois volumes de atas do Congreso de la Asociación de Historiadores Latinoamericanos anterior à constituição formal dos Estados independentes latino-americanos.

Esta é, mais ou menos, a situação atual do debate sobre essa questão. Teria de acrescentar que, nestes últimos anos, surgiu um renovado interesse pelo institucional ao propor-se a teoria de que o arranjo institucional imperial perdurou mais do que originalmente se pensava no processo de emancipação latino-americana e continuou influindo nos conflitos internos dos Estados latino-americanos no século XIX.

Esse desenvolvimento da investigação padeceu, em certa medida, da falta de debates teóricos e de verdadeiras tentativas de generalização. Nós, afora uma incursão na realidade econômica novohispana dos pueblos dos índios - na qual se estudou o sistema dos repartimientos comerciais realizados pelos corregidores e alcaldes mayores -, meditamos e investigamos durante muito tempo o problema do Estado na América hispânica colonial, mantendo até certo ponto a aproximação institucional, ainda que sempre tratando de analisar o significado e o impacto político dos organismos estatais. Assim, em minha tese de doutorado busquei valer-me de aproximações das ciências sociais ao tema, recorrendo a Max Weber, estudando posteriormente a realidade mais chã da administração real na América e o processo do benefício de cargos entre os corregidores ${ }^{5}$.

Europeos (AHILA), 1985, em Florença: ANNINO, Antonio et al. (Org.). America Latina: Dallo Stato Coloniale allo Stato Nazione, 1750-1940. 2 vols. Milão: 1987.

5 Cf. PIETSCHMANN, Horst. Die Einführung des Intendantensystems in Neu-Spanien im Rahmen der allgemeinen Verwaltungsreform der spanischen Monarchie im 18. Jahrhundert. Colonia-Viena, 1972. Alcaldes Mayores, Corregidores und Subdelegados. Zum Problem, der Distriktsbeamtenschaft im Vizekönigreich Neuspanien. In: Jahrbuch für Geschichte von Staat, Wirstchaft und Gesellschaft lateinamerikas. Colonia-Viena, vol. 9, 1972, pp. 173-270. Idem. El comercio de repartimientos de los alcaldes mayores y corregidores en la región de PueblaTlaxcala en el siglo XVIII. Simposio Hispanoamericano de Indigenismo Histórico, Terceras Jomadas Americanistas de la Universidad de Valladolid, Valladolid, 1977 (resumo de um estudo mais extenso publicado em alemão no vol. 10, de 
Mais tarde, pretendeu-se declinar o processo político de criação de estruturas estatais no século $\mathrm{XVI}^{6}$, sempre atento ao progresso da investigação sobre a economia e a sociedade. Em princípios dos anos oitenta, propusemos como elo entre o desenvolvimento autonômico das sociedades coloniais, cada vez mais evidente, e o aparato governativo metropolitano e suas normas legais - normas que traduzem uma política metropolitana inspirada nos modelos econômicos e sociais europeus de cada época -, o fenômeno da corrupção que, desde a formação das sociedades coloniais no primeiro terço do século XVII, converte-se em sistemático. Desde tal ponto de vista, entendia-se a corrupção como um mecanismo de negociações e arranjos entre a Coroa e as sociedades coloniais, efetuados por uma burocracia real, cada vez mais autônoma, e sem ter em conta a legislação existente que, em muitos casos, proibiu expressamente tais arranjos que se realizavam.

Logo se introduziu, sem definição precisa, o conceito de "Estado colonial", que, de certo modo, parecia responder às realidades constatadas conforme a investigação progredia, conceito que mais tarde foi atacado, sem que esse ataque tenha produzido o debate teórico que a grande quantidade de novos conhecimentos no fundo exigia ${ }^{7}$. Outros autores preferiam continuar utilizando o conceito de "pacto colonial" frente à dicotomia entre sociedade(s) colonial(is) e

1973, do Jahrbuch für Geschichte von Staat, Wirstchaft und Gesellschaft Lateinamerikas).

6 PIETSCHMANN, Horst. Staat und staatliche Entwicklung am Beginn der spanischen Kolonisation Amerikas. Münster, 1980. A versão castelhana que incorpora, ademais, o artigo sobre "burocracia e corrupção" (cf. nota n. 7) é: El Estado y su evolución al principio de la colonización española de América. México: FCE, 1989.

7 PIETSCHMANN, Horst. Burocracia y corrupción en Hispanoamérica colonial. Una aproximación tentativa. In: Nova Americana, Turín, n. 5, 1982, pp. 11-37. Para o conceito de "Estado colonial", cf. a nota n. 4 e, também, ver Carlos Malamud Rikles sobre conceito de "Estado colonial" na América hispana (Revista de Occidente, n. 116, jan. 1991, pp. 114-127). Ademais, o problema da corrupção foi amplamente tratado em diversos estudos publicados nos aparato burocrático imperial. Este pacto colonial fora redefinido conforme as exigências de cada época até vir a romper-se de forma definitiva às vésperas das guerras da Independência desencadeadas pelo reformismo bourbônico ${ }^{8}$. Contudo, esse conceito de "pacto colonial" resulta tão vago quanto o de "Estado colonial”, já que só o utiliza uma parte da sociedade conquistadora $\mathrm{e}$, mais tarde, criolla. A Coroa, de sua parte, não parece tê-lo aceito a não ser no princípio da expansão espanhola na América e, mais tarde, porventura, em termos de um laço de vassalagem - cada vez mais afastado do significado original e concreto que este teve na Idade Média - entre o rei e seus súditos americanos.

Seja como for, ambos os conceitos, o de "Estado colonial" e o de "pacto colonial", nunca foram objeto de um estudo aprofundado baseado nas realidades americanas de cada época. Ademais, ambos os conceitos parecem demasiadamente estáticos para responderem ou poderem adaptar-se à evolução da realidade, em permanente mutação tanto na América como na Península durante os três séculos de domínio da Coroa de Castela - mais tarde de Espanha - na América. Finalmente, fica por comprovar que o conceito de Império espanhol na América venha a responder às complexas realidades dos processos históricos em ambos os lados do Atlântico, já que nele predomina a perspectiva metropolitana. Quando muito, poderiam caracterizar-se os

anos oitenta. Eduardo Saguier abordou-o de forma mais sistemática em vários artigos (cf. La corrupción administrativa como mecanismo de acumulación y engendrador de una burguesía nativa. In: Anuario de Estudios Americanos, Sevilla, vol. XLVI, 1989, pp. 269303).

8 Cf., por exemplo, MURO ROMERO, Fernando. La reforma del pacto colonial en Indias. Notas sobre instituciones de gobierno y sociedad en el siglo XVII. In: Jahrbuch... lateinamerikas, nota n. 5, vol. 19, 1982, pp. 4768. É impossível fazermos referência, aqui, a todos os autores que empregam o termo "pacto colonial", porém, até onde podemos saber, parece-nos que esse conceito é um dos tantos com frequência manejados sem terem sido claramente definidos. 
aludidos processos qualificando-os de "auge" ou "enfraquecimento", inclusive até de "decadência" ou termos similares, com o que se esconderiam ou subvalorizariam os processos de criação de novas entidades e identidades históricas no solo americano. Estas entidades - ou identidades ganham, ao longo da época moderna, tanta força que chegam primeiro a um nível considerável de autonomia e, finalmente, ultrapassam em importância as forças da metrópole e de seus representantes na América, ao produzir-se a emancipação e constituição dos Estados independentes.

Já não há dúvida de que, a partir de uma perspectiva da história das estruturas, há de se buscar na época colonial os antecedentes da independência e da constituição efetiva dos Estados independentes latino-americanos. De modo que os velhos debates latino-americanos sobre as causas e os antecedentes da emancipação na época colonial, que já desde os anos trinta do século $\mathrm{XX}$ pretendiam encontrar em qualquer rebelião um antecedente da emancipação, e que foram em grande parte rechaçados pela historiografia não nacionalista, ganham agora novo sentido à luz das estruturas econômico-

\footnotetext{
9 La Colección Documental del Bicentenario de la Revolución Emancipadora de Túpac Amaru (5 vols., Lima, 1980-1982), insiste, todavia, na velha tradição latinoamericana de se referir a rebeliões coloniais como antecedentes da emancipação estatal. A bibliografia sobre as variantes estruturais do Império espanhol na América é abundante. A perspectiva se reflete bastante bem nos volumes correspondentes da Cambridge History of Latín America, especialmente no vol. 2 (Cambridge, 1984), apesar de seu enfoque generalizador. De forma mais sucinta, Marcello Carmagnani resume esse fenômeno em sua colaboração no vol. 1 do Handbuch der Geschichte Lateinamerikas (Stuttgart, 1994, no prelo).

${ }^{10} \mathrm{Cf}$. SAINT-LU, André. Condition coloniale et conscience créole au Guatemala. Paris, 1970. De certo modo, Saint-Lu foi pioneiro dos estudos sobre o criollismo. LAVALLÉ, Bemard. Recherches sur l'apparition de la conscience créole dans la vice-royauté du Pérou: l'antagonisme hispano-créole dans les ordres religieux (XVI ${ }^{e}-X V I I^{e}$ siècle). 2 vols. Lille, 1982; e Las promesas ambiguas. Ensayos sobre el criollismo colonial en los Andes. Lima, 1993. Veja-se, também, BRADING, David A. The First
}

sociais que estão se perfilando e cujas transformações ao longo da época colonial se delineiam de maneira cada vez mais precisa ${ }^{9}$. Finalmente, a linha de investigação que se havia ocupado da análise da consciência criolla destacou com bastante clareza o surgimento de uma identidade desse tipo, que em alguns casos é identificada vagamente como "americana", em geral, e em outros casos, de modo mais concreto, especialmente nas regiões em que dita busca de identidade podia de alguma maneira recorrer ao passado das grandes culturas indígenas préhispânicas, como no México e no Peru. E ainda mais: frente ao antigo conceito formalista de que o criollo é um espanhol nascido na América, surgiu uma definição que vinculava mais concretamente ao criollo às estruturas econômicas e sociais, e que caracterizava como criollos as pessoas que tinham a base econômicosocial de sua vida em uma das muitas regiões da América e que pertenciam, ao mesmo tempo, ao grupo oligarca de seu âmbito regional ${ }^{10}$.

O que significa tudo isso para a história do desenvolvimento estatal? Segundo nosso modo de ver, antes de tudo, impõe-se uma conclusão metodológica: o processo histórico do Estado na

America. The Spanish Monarchy, Créole, Patriots and the Liberal State, 1492-1867. Cambridge: Cambridge University Press, 1985 (edição castelhana: Orbe indiano. De la monarquía católica a la República criolla, 14921867. México: FCE, 1993). No caso do México, é imperativo referir outro grande predecessor: LAFAYE, Jacques. Quetzalcóatl et Guadalupe. La formation de la conscience nationale au Mexique, 1631-1813. Paris, 1974 (edição castelhana: Quetzalcóatl y Guadalupe. La formación de la conciencia nacional en México. México: FCE, 1977). A partir da perspectiva da história do nacionalismo, a fácil equiparação entre criollismo consciência nacional - nacionalismo, apresentada nesses estudos, parece-me, contudo, problemática. Na Europa se considera a portadora dessa consciência é a classe burguesa; o que parece difícil é equiparar os criollos americanos com os burgueses europeus. Jochen Meissner analisa o debate sobre "raça", "classe" e estratificação social no México colonial tardio e o compara com os debates europeus, em particular os alemães, sobre o mesmo tema (Eine Elite im Umbruch. Der Stadtrat von Mexiko zwischen kolonialer Ordnung und unabhägigem Staat. Stuttgart, 1993). 
América espanhola deve receber um duplo enfoque: a perspectiva metropolitana e a propriamente hispano-americana. A primeira se caracteriza por todo um conjunto de transferências à América de instituições e de conteúdos político-mentais que se enraizaram neste continente. Por outro lado, a perspectiva hispano-americana se caracteriza, no início, por um escasso grau de institucionalização (como será exposto na sequência), mas, mais do que tudo, pelo aporte que supõe a criação de estruturas socioeconômicas, de identidades e idiossincrasias americanas e regionais. Durante bastante tempo, ambas as esferas coexistiram com relativa separação ou, quiçá melhor, como uma superposição das estruturas imperiais sobre as americanas, regionais e locais. No século XVII, ocorre uma interpenetração das esferas com a aproximação da burocracia imperial às realidades socioeconômicas americanas e com a maior infiltração da sociedade criolla nas estruturas burocráticas imperiais e a gestão de seus próprios interesses por meio da mesma burocracia imperial.

A partir de então se inicia um processo que permite à sociedade criolla servir-se de, ao menos, uma porção da estrutura burocrática imperial para seus próprios interesses. Poder-seia afirmar que, desde então, as sociedades coloniais conseguiram maior acesso às instituições administrativas que detinham o monopólio da transformação de interesses em política e em normas legais. Começa, assim, uma fase de relativa autonomia para as sociedades criollas, uma autonomia que funciona em grande parte com manobras que a legislação

\footnotetext{
11 Sobre os grupos de poder existe uma bibliografia abundante: CALVO, Thomas. Círculos de poder en la Guadalajara del siglo XVIII y la Nueva Galicia en los siglos XVI y XVII. México, 1989. RAMÍREZ, Susan E. Land Tenure and the Economics of Power in Colonial Peru. Albuquerque, Nuevo México, 1986. LAVALLÉ, Bernard. Le Marquis et le Marchand. Les luttes de pouvoir au Cuzco (1700-1730). Paris, 1987. Não obstante, o autor tende a apresentar seu caso como exemplo do antagonismo criollo-
}

metropolitana proibia, como, por exemplo, a interpretação laxa da legislação metropolitana para adaptá-la a situações e interesses locais ou regionais, e, inclusive, diretamente o suborno e a corrupção de indivíduos ou grupos da burocracia imperial. Parece que, desde esse momento, começa a formação de um processo que facilita à população enquadrada nas estruturas socioeconômicas regionais uma articulação política mais ou menos coletiva, fato que se poderia conceber também como o início da formação de entidades proto-estatais na América hispânica por debaixo de uma estrutura imperial que se debilitou mais e mais conforme o processo avançava.

Dita interpretação apresenta, no entanto, um grave obstáculo: a falta de homogeneidade das sociedades criollas, inclusive no nível regional. A história social do último decênio deixou muito patente que as sociedades criollas estavam em contínua transformação em razão de novos elementos sociais que a elas tiveram acesso, enquanto que outros descendiam econômica e socialmente. Além disso, tais sociedades eram compostas de múltiplos grupos de poder, organizados vertical e horizontalmente com estruturas de clientelismo, parentesco e compadrio. Esses grupos rivalizam uns com os outros, e, assim, em muitas ocasiões desmentem a suposta solidariedade criolla $^{11}$. Ademais, há indícios de que também entre mestiços e castas e entre os índios se produziram processos de conscientização e de solidariedade que fizeram as

peninsular, ainda que, segundo sua própria definição, o comerciante também seja um criollo, um criollo de nova "estirpe". Conviria, pois, apresentar o caso como o da luta por ascensão social frente a interesses oligárquicos já estabelecidos: problema de mentalidade social ou problema de origem geográfica? Limitamo-nos a mencionar os exemplos antes mencionados dentre a plêiade de estudos acerca do fenômeno das lutas de grupos de poder. 
sociedades criollas se revelarem, contudo, mais fracionadas ${ }^{12}$.

Esses resultados da história social recente complicam bastante o panorama, já que assim só restam como contrapartida das estruturas burocráticas imperiais as estruturas sociais e econômicas definidas à base de generalizações de médio alcance. Primeiro, há de se definir até que ponto realmente existiu uma solidariedade acima dos interesses de grupo - mais além das facções, partidos e grupos de parentesco ou de clientela, que competiam entre si - e, se for o caso, desde quando esta chegou a ser efetiva na esfera política frente às estruturas imperiais, como sugerem os estudos sobre o criollismo. Além disso, convém insistir também no tema da consciência e solidariedade dos outros grupos sociais, como índios e castas, por exemplo. Neste campo, seguramente a história das mentalidades ainda poderá contribuir bastante para esclarecer as relações coloniais à medida que se aproxima de modo mais sistemático às mentalidades dos diferentes grupos sociais. $\mathrm{O}$ certo parece ser, em

\footnotetext{
${ }^{12}$ Para o caso dos índios, cf. CARMAGNANI, Marcello. $E l$ regreso de los dioses. El proceso de reconstitución de la identidad étnica en Oaxaca. Siglos XVIII y XIX. México, 1988. Menos claro é o caso das castas - os grupos com mescla de sangue -, porém há indícios de que se servem, segundo a oportunidade, de sistemas de valores diferentes para tentar melhorar sua posição social; cf. o caso referido no Real de Minas de Zimapán, aos fins do século XVIII, em PIETSCHMANN, Horst. Estado colonial y mentalidad social: el ejercicio del poder frente a distintos sistemas de valores, siglo XVIII. In: ANNINO, Antonio. et al. (Org.). America Latina: Dallo Stato Coloniale allo Stato Nazione, 1750-1940. $2^{\circ}$ vol. Milão, 1987. p. 427-447.

${ }^{13}$ A afirmação de ser "índio puro, filho de outro tal" se encontra, com pequenas variações, em representações de índios novo-hispanos às autoridades administrativas. Entretanto, haveria de se rastrear se esse tipo de afirmação étnica provém de índios de comunidade, nobres ou não nobres, ou de índios integrados à sociedade colonial urbana e criolla. Parece quem neste contexto, existiu toda uma variedade de mentalidades e afirmações distintas. Assim, por exemplo, no Archivo General de Indias (AGI), Audiencia de México, arquivo 685, se encontra um expediente sobre as monjas do convento de Santa Clara para índias nobres, no qual se discute, entre outras coisas, a religiosidade e a capacidade intelectual das monjas índias. No expediente se encontram vários expedientes de índios
}

todo caso, que na segunda metade do século XVIII parecem conviver distintas mentalidades na América espanhola, como, por exemplo, uma criolla oligárquico-estamental, outra de mentalidade mais criolla-competitiva, compartilhada por grupos sociais em ascensão e, às vezes, de composição racial mista -, e outra mentalidade mais de afirmação indígena, a qual se vê refletida em numerosos documentos nos quais os índios afirmam que são "índios puros, filhos de outros tais" $" 13$.

Em todo caso, o certo parece ser que a época em que todos estes processos germinam é o século XVII ou, mais concretamente, os anos entre o começo do reinado de Felipe IV e o final do reinado de Carlos II. Neste lapso se podem observar, por um lado, uma mudança na política da Coroa e, por outro, as primeiras manifestações, bastante bem definidas, do espírito criollo, a aparição de estruturas socioeconômicas coloniais consolidadas e o início não somente da recuperação demográfica indígena, mas também de sua reafirmação étnica.

que se qualificam como membros da "nobreza desta nação mexicana", e que reclamam, não somente já na primeira metade do século XVIII, para si o status de nobres, mas também o de ser representantes da "nação mexicana", quando já entre os criollos também existe uma consciência diferente de "nação mexicana". Na representação de dois frades franciscanos e da monja fundadora do convento, Irmã María Teresa de San Joseph, se lê como rechaçou os detratores do convento, entre outras coisas: “[...] que ditos curas falaram das Índias Agrestes, montesinas e que não estão criadas em lugares políticos; nós falamos de Índias Religiosas a quem Deus N. S. deu a vocação da Religião, criadas entre espanhóis e tão polidas que nem com o idioma castelhano se envolvem, e seu interior comunicam no Confessionário como a mais discreta das espanholas. Sucede nesta Nação, Senhor, o que em todas se experimenta, que segundo o maior ou menor cultivo e trato com gente versada no racional, avançam mais ou menos na discrição, e neste ponto só dizemos que, com uma única hora de trato de ditas Religiosas, o menos sensato experimenta sua discrição e racionalidade junto com a edificação e honestidade religiosas que lhe será notória pela visão e pelo ouvido". Faltam, desde já, estudos que analisem o significado do termo "nação", que aparece com frequência em textos coetâneos. 
Em suma, todos os processos que, de um modo ou outro, deve-se ter em conta ao analisar o desenvolvimento da formação estatal sobre a base de uma maior interpenetração entre estruturas e processos coloniais e das superestruturas imperiais que se iniciam naquela época. De outra parte, há de se afirmar que, apesar de todos os progressos da investigação histórica dos últimos tempos, o século XVII hispano-americano se ressente ainda do longo olvido ao qual foi relegado pelos historiadores. Apesar do início de uma corrente historiográfica dedicada ao século XVII desde os anos setenta e, depois, robustecida durante os oitenta, a massa da produção historiográfica sobre a América hispânica colonial ainda está centrada no século XVI e na segunda metade do século XVIII. É forçoso concluir que a época que ao parecer representa o início do auge e da afirmação do propriamente hispano-americano e, ao mesmo tempo, o início do declive das estruturas imperiais, é, todavia, a menos conhecida, ao menos relativamente, de todo o período colonial hispano-americano. Isso dificulta enormemente a possibilidade de apreciar muitos dos fenômenos que consideramos essenciais para o processo de formação das estruturas estatais na América espanhola.

Por outro lado, também é necessário assinalar que o substrato metropolitano que veio a influir na articulação da política e da legislação metropolitana para a América é bastante pouco conhecido. A história institucional e política que se ocupa da América parte ainda de uma continuidade com o século XVI que pouco parece corresponder à realidade. Assim, por exemplo, é óbvio que, no que concerne à política fiscal, às

\footnotetext{
${ }^{14}$ Ver SANDOVAL, Fernando B. La industria del azúcar en Nueva España. México, 1951. O autor afirma que, na época de Felipe II, a Coroa tratou de cortar a produção açucareira para fomentar, em troca, a das ilhas do Caribe, Cuba e La Española em particular, por carecerem estas de outros recursos econômicos.

${ }^{15}$ ENCINAS, Diego de. Cedulario indiano. 4 vols. Madrid, 1945-1946 (primeira impressão em: Madrid, 1956).
}

projeções de conceitos sociais para a América e à aplicação e colocação em marcha da política, existem inovações que foram pouco estudadas ou, pior, inclusive negadas por uma parte da historiografia, que nega a importância, por exemplo, da história das ideias. Deste modo, por vezes se rechaçam fatores novos, como o absolutismo, que, se bem é certo que seu impacto deve ser relativizado, modificou sim os princípios básicos da maneira de governar que, inclusive, projetou um modelo de sociedade diferente em suas normas político-legais.

Não, há, por exemplo, estudos sistemáticos sobre a política social e econômica da Coroa com relação à América, apesar de haver indícios de que até houve tentativas de orientar a economia colonial de acordo com os princípios de complementaridade, mediante o qual se fomentavam determinados produtos para umas regiões e se proibiam para outras ${ }^{14}$. Por outro lado, quanto à política social, ninguém se preocupou em analisar as circunstâncias por detrás dos enormes esforços que se empreenderam desde as duas últimas décadas do reinado de Felipe II até o final do reinado de Felipe III para organizar ao longo do Império agremiações de artesãos. Os autores que tratam desses temas gerais recorrem a textos legais como o Cedulario de Encinas, a Recopilación ou a grande obra de Solórzano Pereira ${ }^{15}$, sem ter em conta que essas obras refletem os princípios básicos de governo de determinados momentos e que a política sobre determinados assuntos só pode ser captada na torrente de cédulas reais, provisões e pragmáticas para as distintas regiões americanas. No que diz respeito ao governo, por

Recopilación de leyes de los reynos de las Indias. 3 vols. Madrid, 1943 (primeira impressão em: Madrid, 1680). Solórzano integrou o Consejo de Indias depois de servir em vários cargos na América. Considera-se sua obra como a fixação de invariáveis de governo que orientou a política metropolitana. 
exemplo, ninguém se fixou apenas no incremento importante de funções comissárias que se pode observar ao longo do século XVII, isto é, o exercício do poder mediante funcionários nãopermanentes a quem se encarrega a resolução de determinados assuntos mais além do funcionamento rotineiro das instituições clássicas ${ }^{16}$.

As alterações profundas em tantos setores do governo e da vida econômica e social, postas em destaque por José Antonio Maravall em seu grande livro sobre a Espanha entre os séculos XV e XVII ${ }^{17}$, não encontraram, todavia, um historiador que analisasse essa temática na América espanhola dos séculos XVI e XVII. Por incrível que pareça, há de se concluir que a política que a Espanha levou a cabo em relação à América é mais desconhecida em seus detalhes do que os processos históricos na própria América, apesar de haver indícios claros que sinalizam que esta política não se cingiu apenas a buscar o aumento das rendas reais ou da produção de prata e a robustecer, de tempos em tempos, o controle real sobre o conjunto americano. Tal imagem é mais a consequência de uma historiografia reducionista que, ou não conhece, ou não toma em conta o amplo panorama da história europeia que influiu nesta política americana.

\footnotetext{
16 PIETSCHMANN, Horst. Antecedentes españoles e hispano-americanos de las Intendencias. In: Memorias del Cuarto Congreso Venezolano de Historia, 27 de octubre- ${ }^{\mathrm{er}}$ de noviembre de 1980, 3 vols., Caracas, 1983, $2^{\circ}$ vol., pp. 431-481, onde se buscou uma aproximação geral ao tema. Muitas das comissões individuais foram estudadas nos distintos congressos de história do direito indiano. Cf. HERA, Alberto de la; BARRERO, Ana María; MARTÍNEZ DE CODES, Rosa María. La historia del derecho indiano. Aportaciones del Instituto Internacional de Historia del Derecho Indiano a la bibliografía jurídica americanista. Madrid, 1989, onde se reuniram as apresentações dos oito primeiros congressos.

17 MARAVALL, José Antonio. Estado moderno y mentalidad social. Siglos XV a XVII. 2 vols. Madrid, 1972.

${ }^{18}$ KONETZKE, Richard. Colección de documentos para la historia de a formación social de Hispanoamérica, 14931810. 3 volumes em 5 tomos. Madrid, 1953-1962. Do mesmo autor, Süd und Mittelamerika I. Die Indianerkulturen Altamerikas und die spanisch-
}

O único historiador que de forma sistemática estudou dita política nos anos do pósguerra foi Richard Konetzke ${ }^{18}$, a cujos trabalhos se recorre ainda quando se trata da "política americana", sem ter em conta que os conhecimentos da historiografia sobre a Europa daquela época, inclusive a Espanha, aumentaram consideravelmente e que já seria hora de revisar a política metropolitana para a América à luz dos novos conhecimentos. De modo que temos de partir de uma situação na qual sabemos muito sobre as mudanças estruturais na América ao longo da época colonial, enquanto que a política imperial se apresenta ainda de forma quase estática. Esta havia sido concebida na época de Carlos V e continuada com pequenas mudanças ao longo da época dos Habsburgos, para depois ser substituída por uma política mais mercantilista pelos primeiros Bourbons e, mais tarde, pela "revolução no governo" 19 produzida pelo reformismo de Carlos III e de Carlos IV.

Por tudo o que se sabe da história política europeia daqueles séculos, tal visão da América espanhola parece simplesmente absurda e ahistórica. Uma boa análise da política metropolitana na Europa em relação à América teria que partir de novo do Consejo de Indias, como há tantos anos o fez, com um enfoque mais

portugiesche Kolonialherrschaft. Fischer Welteschichte. Vol. 22. Frankfurt, 1965 (edição castelhana: América Latina II. La época colonial. Historia universal. Madrid: Siglo XXI, 1971). KAHLE, Günter; PIETSCHMANN, Horst. (Eds.). Lateinamerika. Entdeckung, Eroberung, Kolonisation, Gesammelte Aufsätze von Richard Konetzke. Colonia-Viena, 1983 (esta coleção inclui os artigos mais importantes de Konetzke, dos quais a maioria está escrita em castelhano).

${ }^{19}$ Este termo foi introduzido por David Brading (Miners and Merchants), referindo-se à introdução do sistema de intendências e demais reformas introduzidas por José Gálvez na Nueva España. Consideramos que as reformas foram mais do que uma revolução do sistema de governo, já que, segundo uma formulação mais restrita ou mais ampla, as reformas não só significaram um ataque ao poder criollo, mas também um ataque aos grupos oligárquicos em geral e, em especial, contra as corporações ou instituições jurídicas que haviam permitido a consolidação do poder das oligarquias. 
institucional, Ernesto Schäfer ${ }^{20}$. E haveria de estudar de forma sistemática o que desde ali se projetava para o conjunto dos reinos e províncias na América, tendo em conta as particularidades básicas de cada região em suas estruturas econômico-sociais. Apesar de se haver insistido tantas vezes na carência de informação do Consejo de Indias sobre a realidade americana, cremos que dito organismo conhecia as diferenças regionais, a composição demográfica e social e as estruturas econômicas bastante melhor do que se supõe e que as havia levado em conta.

\section{AS ORIGENS DOS FUTUROS ESTADOS}

Afora as fraquezas e déficits do estado da investigação, coloca-se o problema conceitual. Já dissemos que o uso do termo Imperio español en América nos parece pouco adequado, pois, no fundo, só permite caracterizar os processos históricos através do tempo com qualificativos como auge, estancamento e declive, o que encobre o surgimento de novas entidades históricas na América. Este conceito tem sentido unicamente na perspectiva da história da Espanha, porém não tem nenhum na perspectiva americana, a partir da qual o questionamento do historiador é, ao fim e ao cabo, o de entender como surgiu a América Latina moderna com seu sistema atual de Estados, suas respectivas estruturas sociais, econômicas e políticas tal e como estas se apresentam em toda a sua complexidade desde o século XIX. Para o historiador, há de rechaçar-se a ideia de que os Estados atuais surgiram do antigo Império espanhol ao longo das guerras de independência em um processo complicado e penoso, por intervenção de uma espécie de deus ex machina. Pelo contrário, podemos afirmar que estes futuros Estados estavam sendo incubados e

\footnotetext{
${ }^{20}$ SCHÄFER, Ernesto. El Consejo Real y Supremo de las Indias. Su historia, organización y labor administrativa hasta la terminación de la Casa de Austria. 2 vols. Sevilla, 1935-1947. O volume editado por Demetrio Ramos ( et al. El Consejo de las Indias en el siglo XVI. Valladolid,
}

perfilados desde muito antes, mediante processos históricos complexos dos quais resultou, no território das futuras novas nações, o surgimento de forças suficientemente fortes e coerentes para finalmente constituírem-se em neste ou naquele país independente.

É evidente que essas forças não surgiram de maneira autônoma, mas em interação permanente com as estruturas administrativas imperiais, posto que todos os novos Estados se constituíssem no marco de divisões administrativas coloniais, ainda que depois apareçam muitos pleitos fronteiriços que, em grande parte, são devidos à imprecisão das fronteiras das entidades administrativas coloniais. O mesmo conceito de demarcação administrativa faz parte do processo de prefiguração dos Estados independentes posteriores e até agora somente foi estudado de maneira muito parcial. Contudo, há Estados independentes que se foram com base em simples gobernaciones coloniais, como Uruguai, Paraguai e a maior parte dos Estados centroamericanos. Outros se constituem tomando como base distritos de audiencias, como Chile, Bolívia, Equador e Venezuela e, outros, finalmente, a partir de vice-reinados, como México, Colômbia, Peru e Argentina, surgindo, é claro, de vicereinados dos quais já se haviam destacado os territórios mencionados.

Deve-se partir, então, do suposto de que cada um dos novos Estados independentes tinha a coesão suficiente para controlar mais ou menos, desde seu centro administrativo, o território sobre o qual se constituiu. Isso significa, por um lado, que a maior parte dos vice-reinados não tinha autoridade suficiente em toda sua extensão territorial de modo a aglutinar de forma duradoura determinados territórios e, vice-versa, que algumas entidades administrativas tinham tanta

1970) amplia a visão prévia de Schäfer, ainda que tampouco analise, de maneira sistemática, a política econômica, social etc. que este organismo articulou, cingindo sua análise a aspectos parciais: medidas frente a determinados problemas, grupos sociais, etc. 
coesão e identidade que logravam emancipar-se de suas instâncias administrativas superiores na América. É evidente que na constituição destas identidades influíram de maneira decisiva as estruturas sociais, porém, também é certo que tais estruturas estavam coesas em torno a determinadas entidades administrativas. Isso significa que a capacidade aglutinadora das instituições era muito maior do que alguns setores da historiografia econômica e social costumam admitir.

Partindo de tais considerações, parece-nos que o termo "formação proto-estatal" é, ao menos no momento e na falta de um conceito mais adequado, o mais apropriado para caracterizar esse processo de interação entre as forças econômico-sociais e as estruturas burocráticas imperiais, o qual finalmente desembocou na constituição de Estados independentes. Dita interação se dá, certamente, em toda a época colonial, porém, é no século XVII quando, afora certas entidades caracterizadas por determinadas estruturas econômico-sociais, começa a captar-se claramente uma consciência de grupo nas principais manifestações do espírito criollo, o que dá uma nova qualidade ao complexo estrutural socioeconômico, um espírito de coesão e de vinculação a um território delimitado por certas circunscrições administrativas territoriais. Daí que a aplicação do conceito "formações protoestatais" ganhe sentido mais ou menos desde o último terço do século XVII, ao menos para as regiões centrais do Império americano espanhol, ou seja, a Nova Espanha propriamente dirá e o complexo Peru e Alto Peru. Para outras regiões, provavelmente seria necessário modificar a periodização.

Já no século XVII é possível precisar com bastante clareza as regiões ou jurisdições com muitas características estruturais próprias e ao mesmo tempo com um alto grau de autonomia administrativa dentro do arranjo institucional imperial. Assim, por exemplo, Chile e Paraguai,
Quito, Nueva Granada, Venezuela, as presidências e capitanias gerais de Guatemala, Cuba e Panamá se articulam bastante claramente, tanto no nível socioeconômico quanto a certa autonomia política. Em outras áreas, percebem-se à época fortes rivalidades entre zonas estreitamente unidas política e administrativamente - porém com perfis estruturais próprios - como é o caso do conjunto Peru e Alto Peru, do México/Nova Espanha e da área controlada pela audiencia de Guadalajara, por um lado, e Yucatán, por outro. A frequente competição entre as autoridades de uma e outra região em ambos os complexos vice-reinais atesta a situação muito claramente no que se refere a assuntos de governo.

E o que quiçá apoie com mais força esta teoria é o simples fato de que no século XVII surge o conceito de "superior gobierno" frente ao governo simples. Este termo, que não aparece na legislação até finais do século XVIII e que na historiografia não foi estudado de maneira coerente, é um claro testemunho de o arranjo institucional, criado no século XVI, é posto em julgamento pela simples dinâmica dos processos históricos. Tudo isso contribuía para que se concentrasse, em determinadas regiões e hierarquias da pirâmide institucional, um poder superior ao legalmente vigente.

Neste contexto, deve-se afirmar que o menosprezo que grande parte da historiografia mostrou durante muito tempo aos conflitos de competência entre hierarquias burocráticas foi um grave erro. À medida que se conhecem melhor os mecanismos de funcionamento dos grupos de poder e suas tentativas de influir na burocracia para alcançar decisões burocráticas ou legais em seu favor, resulta evidente que esses pleitos de competência não eram só originados do capricho de funcionários demasiadamente apegados à promoção de sua própria posição social, mas que em muitos casos se tratava de lutas de poder no seio da mesma burocracia, conclusão que, diga-se 
de passagem, salta à vista de quem se presta a ler a documentação, às vezes enorme.

Os historiadores das instituições não se ocuparam desta problemática durante muito tempo e, se não fosse por historiadores provenientes mais da história social, o problema não haveria sido abordado ${ }^{21}$. O significado político desse fenômeno, contudo, foi pouco analisado até o momento. Em todo caso, a respeito do termo "superior gobierno", pode-se observar que as faculdades que se derivam dele são, a partir do século XVII, disputadas com muita frequência com os vice-reis por parte dos presidentes de audiencias que, ao mesmo tempo, são capitanes generales e governadores de uma circunscrição determinada, e até por simples capitanes generales e governadores. Em alguns casos, os vice-reis conseguiam impor-se; em outros, não. É esse tipo de pleitos que determinam o maior ou menor grau de autonomia administrativa e política de umas ou outras regiões. Até o momento, sabese muito pouco dos critérios segundo os quais, a Coroa sentenciou em tais casos em última instância, apesar de se tratar de um problema de importância política primordial. É com base em tais conflitos que fomos delineando o esquema antes exposto de entidades administrativas com maior ou menor grau de autonomia ou de entidades em conflito. Entretanto, as limitações de tempo e de espaço em um estudo como este impedem desenvolver e documentar em detalhes as afirmações expostas. Seria esse um tema para um livro inteiro.

Neste contexto, é preciso assinalar também que a Coroa influiu, já desde o princípio da criação do aparato burocrático imperial, no

\footnotetext{
${ }^{21}$ Não há estudos, de acordo com o que sabemos, sobre a origem do conceito "superior gobierno". Discutimo-lo no contexto das reformas bourbônicas em nosso livro sobre as intendências (citado na nota n. 5). Já em 1628, o marquês de Guadalcázar, vice-rei do Peru, alude aos dois tipos de governo dos quais se incumbe, ao dizer que em uma região determinada o vice-rei exerce o "governo universal", enquanto que em um território muito mais extenso lhe é
}

processo de maior ou menor acumulação de poderes administrativos com base, obviamente, nas realidades encontradas na América. Dotou algumas regiões de um simples governador e a outras de um governador e capitán general. Áreas mais importantes foram ainda dotadas de uma audiencia com um presidente que, ao mesmo tempo, detinha os cargos de governador e capitán general, e instituiu finalmente os vice-reinados no México e em Lima (mais adiante será explicado o conteúdo de cada um destes cargos e a diferença entre seu sentido legal e político).

Em todo caso, convém insistir que a forma de acumulação dos cargos nas mãos de um funcionário era expressão do afã de inaugurar uma hierarquia administrativa com clara divisão de faculdades e competências segundo os distintos níveis regionais, posto que somente em casos muito raros o âmbito territorial de jurisdição e mando que correspondia a cada um desses cargos era o mesmo. A área de influência de um vice-rei como tal era muito mais extensa que as funções que ele exercia como presidente de uma audiencia. Com este cargo, o mesmo vice-rei mandava em um território mais extenso que em sua função de capitán general e só sua autoridade de governador era igual em extensão à que tinha como capitán general. Este mecanismo legal resultou pouco adequado na prática e em grande parte originou a introdução paulatina do conceito de "superior gobierno".

Se apesar dessas limitações da autoridade exercida em razão de cada cargo surgem, em algumas áreas, disputas pelo "superior gobierno" no século XVII e XVIII, isso é boa prova de que o mecanismo de acumulação de cargos já não

designada a "superintendência". Com este segundo termo não se refere, aparentemente, a um cargo determinado, mas a uma espécie de superioridade pouco definida. Cf. PIETSCHMANN, Horst. Antecedentes (citado na nota $\mathrm{n}$. 16). O significado dos pleitos de competências aparece de forma indireta em muitos dos estudos sobre os grupos de poder; cf., por exemplo, a bibliografia citada na nota n. 11 . 
bastava para definir o âmbito de mando; também quer dizer que certos fatores externos ao ordenamento jurídico desta hierarquia imperial ganhavam cada vez mais força e influíam mais na autoridade real que o que qualquer das hierarquias administrativas exercia ou, ao menos, aspirava a exercer. Fatores como distância, densidade demográfica, peso econômico ou ameaça militar externa ou interna (por exemplo, a dos índios ainda não integrados ao sistema colonial) influíam, ao que parece, de forma cada vez mais rigorosa neste processo de redefinição de poderes políticos e administrativos na história colonial. $\mathrm{O}$ fenômeno político das alterações no exercício do poder efetivo sobre determinados espaços foi muito pouco estudado de maneira sistemática, a não ser em estudos jurídico-políticos acerca de uma determinada gobernación, capitanía general, etc.

Tampouco há investigações sistemáticas sobre a atividade legislativa da Coroa para redefinir o status administrativo do espaço americano, quando designava um status hierárquico diferente a uma mesma circunscrição territorial ao elevá-la, por exemplo, de gobernación a gobernación e capitanía general, ou quando rebaixava a uma entidade como esta última a uma simples gobernación. Somente o processo de criação de novos vice-reinados ou audiencias durante o século XVIII foi estudado com interesse na historiografia do século XX. Só

\footnotetext{
${ }^{22}$ Cf. GERHARD, Peter. Geografía histórica de la Nueva España, 1519-1821. México, 1986; e também seus dois livros posteriores sobre o distrito da audiencia de Guadalajara e da zona de Tabasco, Campeche e Yucatán.

23 Em estudos sobre gobernaciones individualizadas, bispados determinados e a administração de rendas reais, seguidamente se encontram dados de índole históricogeográfica. A ampla bibliografia sobre pleitos fronteiriços no século XIX inclui também documentação e informação sobre estes aspectos. As tentativas de construção de atlas histórico-geográficos costumam, entretanto, encerrar muitos defeitos, ou eximem-se de entrar em detalhes. Cf. LOMBARDI, Cathryn L; LOMBARDI, John V. Latin American History. A Teaching Atlas. Madison, 1983. MORALES PADRÓN, Francisco. Atlas histórico cultural de América. 2 vols. Las Palmas de Gran Canaria, 1988.
}

existem histórico-geográficos aprofundados do caso da Nova Espanha graças ao esforço sistemático e prolongado de Peter Gerhard $^{22}$. Para as outras regiões do Império espanhol na América é preciso recorrer a inúmeros estudos individuais, frequentemente sobre outros temas, para poder rastrear a informação pertinente ${ }^{23}$. Por esta razão, não se dispõe ainda de um atlas histórico da América hispânica colonial que mereça tal nome e por isso é sumamente difícil tornar visível e compreensível o processo que denominamos de formação de proto-Estados a partir do século XVII. Desejamos, pois, insistir neste ponto de vista em linhas gerais, em que a investigação dos últimos anos está se concentrando mais em entidades regionais precisas, e se aprofundou muito no conhecimento destas, porém frequentemente se olvidou a visão de conjunto do amplo espaço colonial hispano-americano ${ }^{24}$.

\section{BUROCRACIA IMPERIAL E SOCIEDADE CRIOLLA}

Para entender e apreciar esse processo histórico de interação entre as sociedades coloniais e a estrutura burocrática imperial que os dois Austrias maiores montaram, e preciso assinalar que, com exceção da rebelião de Gonzalo Pizarro no Peru dos anos quarenta do século XVI, esta hierarquia burocrática imperial

FLORESCANO, Enrique. (Coord.). Atlas histórico de México. 1983. Com frequência se encontra na bibliografia a distinção entre províncias maiores e menores, porém, geralmente, os critérios utilizados para distinguir umas das outras restam muito vagos $\mathrm{e}$, frequentemente, não correspondem a jurisdições administrativas concretas. Também a tendência a buscar a origem dessas províncias no processo da conquista parece discutível, posto que há fortes indícios que indicam que se respeitava as divisões indígenas pré-hispânicas muito mais do que se pensava. Cf. VOLLMER, Günter. Mexikanische Regionalbezeichnungen. In: Jarbuch... lateinamerikas, 16 Jahrhunfert, vol. 9, 1972, p. 40-101.

24 Esta visão é agora facilitada, no que respeita às comunicações, pelo livro de SERRERA, Ramón. Tráfico terrestre y red vial en las Indias españolas. Madrid, 1992. 
nunca foi posta em dúvida de forma radical na América. Havia protestos sem fim contra medidas concretas ditadas por tal hierarquia, havia oposição a determinados funcionários e havia até tumultos e rebeliões locais ou regionais contra ela, porém a organização como tal jamais foi questionada. A causa dessa lealdade parece ser dupla: por um lado, os primeiros descobridores e conquistadores estavam acostumados a este novo estilo de governo com uma burocracia extremamente especializada e, em segundo lugar, a lealdade em relação à pessoa do rei, do qual, ao fim e ao cabo, emanava esse aparato burocrático - contra o qual sempre se podia recorrer diretamente à pessoa do monarca - garantiam a aceitação deste e seu reconhecimento como via principal mediante a qual se solucionavam conflitos e se obtinham favores e graças reais.

A historiografia insistiu muito no conflito entre criollos e peninsulares pela ocupação de cargos na hierarquia burocrática imperial ${ }^{25}$. Esse mesmo conflito é boa prova de que a via burocrática para chegar ao rei, para solucionar conflitos e para conseguir decisões legais favoráveis aos próprios interesses era plenamente aceita. Contudo, não se deve exagerar o conflito. $\mathrm{Na}$ hierarquia burocrática estavam sempre presentes os criollos em todos os níveis, ainda que se desse em posições subalternas, como secretários de oficina, escrivães, advogados e

\footnotetext{
${ }^{25}$ Cf. BURKHOLDER, Mark A.; CHANDLER, D. S. De la impotencia a la autoridad. La corona española y las audiencias em América, 1687-1808. México, 1984 (primeira edição em inglês: University of Missouri Press, 1977) e outros estudos dos mesmos autores sobre a mesma temática: LOHMANN VILLENA, Guilhermo. Los ministros de la Audiencia de Lima en el reinado de los Borbones, 1700-1821. Sevilla, 1974. ARNOLD, Linda J. Bureaucracy and Bureaucrats in Mexico City, 1742-1835. Tucson, 1988. Em geral, afirma-se que os Bourbons trataram de frear o poder criollo, porém, até a data, isso só se pode provar no que respeita à hierarquia superior da administração, já que carecemos de estudos sobre o que sucedia em outras esferas. Em todo caso, no nível dos cabildos a introdução de regidores honorarios com Carlos III permitiu que novos elementos do mundo criollo tivessem
}

relatores de audiencia, porteiros etc., de modo que a hierarquia burocrática imperial sempre esteve de alguma maneira enraizada na sociedade criolla. De outra parte, não se deve fiar em demasia no conceito tradicional de criollo que os caracteriza como espanhóis nascidos na América, conceito já várias vezes questionado, porém que se segue utilizando. Mais razoável parece a definição que caracteriza o criollo como pessoa cujo centro de vida social e econômica estava na América. Segunda esta outra definição, também os funcionários nascidos na Península, porém residentes há muito tempo na América, casados aqui, às vezes em cargos permanentes da burocracia - por exemplo, como ouvidor de audiencia ou oficial de uma caixa real - e sem muitas perspectivas de ascensão e traslado, passariam por criollos. Visto assim, o problema do enraizamento da burocracia imperial na sociedade criolla ganha mais claridade.

Por outro lado, é necessário considerar que na Espanha se sabia perfeitamente que um funcionário peninsular que passava à América não podia atuar sem vínculos nem sem certo grau de aceitação por parte do ambiente que o rodeava. De modo que, com exceção da fase inicial do estabelecimento da burocracia imperial, durante a qual se observava uma oposição manifesta contra o sistema burocrático, este estava muito vinculado à sociedade colonial ${ }^{26}$. Até os índios, depois de ter

acesso a postos diretivos nos municípios. Cf. MEISSNER, Jochen. Eine Elite im Umbruch, pp. 123 ss.

${ }^{26}$ A vinculação já se havia alcançado com o emprego, por parte dos escritórios administrativos, de muitos escrivães, postos estes geralmente ocupados por criollos por serem ofícios vendáveis e transferíveis por renúncia e, em consequência, em mãos de pessoas radicadas na América. Cf. LUJÁN MUÑOZ, Jorge. Los escribanos em las Indias Occidentales. México, 1982. Sempre houve, ademais, muitos criollos em cargos administrativos medianos e inferiores, na administração de rendas e, por certo, na administração municipal. Ademais, os memoriais de pretendentes a ofícios, que mencionam geralmente os serviços de seus antepassados, permitem rastrear bem claramente a mudança de peninsular a criollo nos cargos militares e administrativo; cf., por exemplo, RODRÍGUEZMOÑINO, Antonio. Memoriales presentados al Real 
aceitado a nova forma de organização em repúblicas ou comunidades, regidas de acordo com o sistema de governo municipal castelhano, aceitavam a nova hierarquia burocrática e sabiam servir-se dela bastante bem em defesa de seus interesses, utilizando-a até para deslocar a antiga elite indígena dos postos de mando ${ }^{27}$.

Não se deve esquecer que esta hierarquia burocrática imperial também não era tão onipresente como pudera parecer. As distâncias no Império eram enormes $\mathrm{e}$ os centros administrativos relativamente poucos e muito distantes uns dos outros. O número de funcionários reais era bastante escasso frente a uma população não muito numerosa, porém enormemente dispersa nos grandes espaços do Império ${ }^{28}$; com isso, a margem de liberdade individual $\mathrm{e}$, inclusive, dos organismos de autogoverno - os cabildos de espanhóis e os de índios - era bastante grande. E isso apesar de estarem controlados por um representante do reicorregidor ou alcalde mayor -, que por seu isolamento e distanciamento das instituições superiores tampouco podia atuar de modo muito rigoroso nos casos normais. Desta sorte, a realidade do espaço americano e da distribuição demográfica, além das dificuldades de transporte e de comunicações, contribuía decisivamente para reduzir o impacto imediato do aparato burocrático imperial ${ }^{29}$.

Finalmente, os mecanismos típicos de funcionamento deste aparato suavizavam consideravelmente sua própria influência. Os mecanismos obrigatórios de instruir expedientes com opiniões e testemunhos diversos, de pedir consultas a muitas autoridades de distintas

Consejo de Indias (1626-1630). Madrid: 1953; que, aparte apresentar um inventário de fundo preciso, reproduz uma grande quantidade desses memoriais, dos quais muitos foram apresentados por pessoas já enraizadas na América.

27 Cf., por exemplo, DEHOUVE, Danièle. Quand les banquiers étaient des Saints. 450 ans de l'histoire économique et sociale d'une province indienne du Mexique. Paris, 1990. OUVENEEL, Arij; MILLER, Simon. (Eds.). hierarquias, de informar aos superiores, de estudar uma realidade jurídica frequentemente confusa ou contraditória e, em suma, o sistema casuísta predominante - isto é, o estudo de cada caso e problema em forma individual -, prolongava muitíssimo a solução dos pleitos e dos problemas. Dito sistema dava lugar a que as distintas hierarquias administrativas ou judiciais opinassem de forma diversa, o que provocava muitas interpretações abertamente opostas entre estas e a realidade legal, e contribuía, então, a flexibilizar a rotina administrativa e a fazê-la menos taxativa e executiva para as sociedades coloniais e seus membros. E quase sempre que a Coroa impunha normas gerais em razão de um problema concreto, ou por afã de reformar determinadas realidades que, para Madrid, pareciam ser pouco adequadas, surgiam protestos que, baseados em fatos diferentes aos referidos nos textos legais provenientes da metrópole, clamavam pela não-aplicação das normas novamente impostas. Isso, por sua vez, causava novas indignações, testemunhos e pleitos, de modo que a aplicação de um mandato legal poderia ser postergada indefinidamente. E, em último caso, o famoso mecanismo do "obedézcase pero no se cumpla" ("obedece-se, mas não se cumpre") - permitia postergar outra vez a aplicação de uma ordem legal metropolitana.

Esse sistema funcionava com mais eficácia se fosse ante as ordens vice-reinais, já que prolongar um debate deste modo permitia, em muitos casos, deixar algum assunto sem decisão até o final do mandato da pessoa do vice-rei que havia dado uma determinada ordem e, frequentemente, o sucessor, assessorado por

The Indian Community of Colonial Mexico. Fifteen Essays on Land Tenure, Corporate Organization, Ideology and Village Politics. Amsterdam, 1990.

28 SÁNCHEZ ALBORNOZ, Nicolás. La población de América Latina. Desde los tiempos precolombinos al año 2000. Madrid, 1973 (e edições posteriores).

${ }^{29}$ Cf. o livro de Ramón Serrera, Tráfico terrestre. 
outras pessoas, opinava de maneira distinta ${ }^{30}$. Esses procedimentos se fundavam na norma geralmente aceita de que o rei e seus representantes não podiam decidir ou ordenar algo sem prévio conhecimento detalhado do caso e sem consultar as autoridades de cada região afetada. Nesta norma, entre outras, fundou-se o já referido conceito do "pacto colonial". Entretanto, tais normas valiam também para a Península, formavam parte dos princípios de governo da época e eram, em grande medida, o suporte do reconhecimento da autoridade neutral do rei.

Daí que, no final do século XVIII, os reformadores ilustrados da metrópole quiseram cortar tais práticas pela raiz, alegando que a lei se aplica e depois possivelmente se a discute, sua atitude foi considerada como uma forma despótica de governo e provocou uma forte reação que visava alcançar maior autonomia frente ao rei e à metrópole enquanto tal. Uma autonomia que, finalmente, pretendia-se fixar legalmente, como se pode observar em muitos exemplos do final da época colonial e do início do movimento das juntas, depois das abdicações forçadas de Carlos IV e Fernando VII por pressão de Napoleão. Contudo, esta não era a primeira oportunidade na qual a Coroa, mediante mudanças na prática legislativa, tentava impor uma maior uniformidade e normatividade legal no Império americano, como demonstra o "ordenancismo" que tanto relevo ganhou durante o reinado de Felipe II e em diferentes épocas posteriores. Dito "ordenancismo" era a expressão de uma nova forma de governo inspirada em certas ideias que, em geral, costumam ser qualificadas como absolutismo monárquico, esforços que, entretanto, sempre tiveram um impacto limitado, segundo parece, pois não foram estudados ainda

\footnotetext{
${ }^{30}$ Basta revisar as memórias de governo dos vice-reis para ver a quantidade de problemas e conflitos que deixavam pendentes ao abandonar o cargo. Os casos logo se encontram nas memórias de governo de seus sucessores. Cf. HANKE, Lewis. Los virreyes españoles en América durante el gobierno de la Casa de Austria. Perú. 7 vols.
}

em seu conjunto. Ao longo de toda a época colonial, podem-se observar os esforços periódicos da Coroa por impor e homogeneizar as normas de governo na América e em alcançar uma aplicação imediata dos novos princípios de governo. O mecanismo de enviar periodicamente visitadores a algumas regiões do Império com amplas faculdades para reformar a administração é boa prova desses esforços ${ }^{31}$.

$\mathrm{O}$ antagonismo entre sociedade criolla e sistema burocrático-administrativo deve ter sido intenso só em alguns períodos, isto é, no momento de seu estabelecimento e imposição às sociedades conquistadoras. Estas se entendiam salvaguardadas pelo sistema das capitulações entre a Coroa e os chefes das empresas de descobrimento e conquista, interpretadas pelos colonizadores como uma espécie de pacto entre a Coroa e o grupo que sustentava a empresa. Foi durante os períodos de visita, quando a Coroa buscou impor reformas mais profundas, e nas diferentes fases reformistas do século XVIII, quando foram modificados aspectos importantes das estruturas internas americanas. Em face desta perspectiva, que parte de uma situação de conflito latente e intensificado em determinados momentos entre Coroa e metrópole e as sociedades criollas - perspectiva amplamente difundida pelos historiadores que se ocupavam do fenômeno do criollismo -, deve-se ter em conta também outro ponto de vista, relativamente pouco considerado e estudado até o momento, que é mais de caráter positivo e que se impõe na perspectiva da formação dos proto-Estados na época colonial.

Deve-se levantar também a pergunta de até que ponto o sistema administrativo imperial contribuiu para estruturar, organizar e

Madrid, 1978-1980. Hanke também editou as memórias dos vice-reis novo-hispanos na mesma Biblioteca de Autores Españoles, em 5 volumes.

${ }^{31}$ Cf. SÁNCHEZ BELLA, Ismael. Las visitas generales en la América española (siglos XVI-XVII). In: Derecho indiano. Estudios. 2 vols. Pamplona, 1991. 
fundamentar as sociedades coloniais, criando assim as bases institucionais que permitiriam a formação de proto-Estados e, posteriormente, na época da emancipação, a formação de Estados independentes. O simples fato de que a formação dos novos Estados independentes se faça sobre a base de determinadas circunscrições administrativas parece demonstrar a importância desse impacto, tanto mais porque as divisões administrativas internas dos Estados representam também, em grande medida, uma continuidade em relação à época colonial.

Os novos Estados federais, departamentos provinciais etc., nos quais, segundo o tipo de Constituição adotada, subdividiram-se as novas Repúblicas, são, em sua enorme maioria, de origem colonial e, mais concretamente, criação do reformismo ilustrado. Assim, intendencias, gobernaciones e, em alguns casos, subdelegações vêm a constituir o tecido organizativo institucional das novas Repúblicas, e, tudo isso, apesar de sua introdução datar de uma época muito próxima ao processo de emancipação. De modo que haveria que se perguntar também até que ponto as divisões territoriais criadas pela Coroa ao longo da época colonial, e, inclusive, pouco antes da emancipação, no contexto das supostamente tão hostis reformas bourbônicas, não constituíram um processo de formação de proto-Estados, que pode, inclusive, ter constituído o requisito necessário para a criação das Repúblicas independentes.

$O$ fato de que essas entidades administrativas se convertessem, no século XIX, na base dos conflitos entre centralismo e federalismo permite suspeitar que esse conflito não era apenas uma herança da reforma bourbônica, ou seja, uma herança colonial, mas que na época colonial havia regiões cuja

\footnotetext{
${ }^{32}$ Cf. FISHER, John; KUETHE, Allan J.; McFARLANE, Anthony. (Eds.). Reform and Insurrection in Bourbon New Granada and Peru. Baton Rouge; London, 1990. Em geral, os conflitos do século XIX na Colômbia são bastante
}

população tinha, segundo parece, identidade suficiente de modo a aspirar ter seus próprios mecanismos institucionais, mais próximos do que os das antigas metrópoles coloniais tão distantes, e que sua origem era anterior às reformas bourbônicas. É certo que as intendencias se organizavam em grande medida sobre a base de bispados de tradição mais antiga, porém, que essas novas subdivisões territoriais se mantivessem posteriormente no seio das novas Repúblicas parece indicar que existia um grande anseio por um maior grau de institucionalização por uma parte importante da sociedade colonial. Certos conflitos impediram, entretanto, que até o momento se analisasse mais a fundo o significado dessas reformas de governo territorial no processo de formação dos Estados independentes e na continuidade dessas entidades nas Repúblicas independentes. Quiçá o caso de Nova Granada/Colômbia, na qual a introdução de intendencias não foi levada a cabo e onde não existiram, portanto, subdivisões administrativas visíveis para o governo de um Estado independente e que, ademais, teve uma história particularmente conflitiva, poderá servir algum dia como exemplo para estudar esse processo ${ }^{32}$.

\section{PERIODIZAÇÃO}

Após estas considerações introdutórias e antes de rastrear mais de perto o processo políticoinstitucional na América hispânica, é preciso falar algo mais acerca dos problemas de periodização das principais épocas que marcam esse processo que dura três séculos. A primeira fase é, obviamente, a época da conquista e dos primeiros assentamentos na América, caracterizada pelo pactismo das capitulações. Essa fase é determinada cronologicamente pelas principais

conhecidos. Nesse aspecto, seria quiçá instrutivo comparar México e Nueva Granada/Colômbia, tendo em conta as diferentes estruturas geográficas, demográficas e econômico-sociais. 
datas do processo de conquista e colonização. Encerra-se definitivamente com a segunda criação de Buenos Aires em 1580; porém, em outras regiões, conquistadas anteriormente, termina muito antes.

A segunda fase, que se sobrepõe fortemente à primeira no que se refere à cronologia do processo de conquista e colonização, pode ser caracterizada pelo avanço progressivo do absolutismo real e o estabelecimento das estruturas administrativas imperiais, e tem, por consequência, a eliminação dos grupos dirigentes das hostes conquistadoras dos cargos militares, judiciais, de governo e mando militar e do ordenamento legal fundamental. A esta fase também pertence, fato frequentemente esquecido, a destruição definitiva das estruturas políticas senhoriais dos impérios indígenas, com o deslocamento dos antigos "senhores naturais" indígenas do mando político. Pode-se duvidar se esta fase começou com a retirada de Colombo do mando de La Española ou com o estabelecimento da primeira audiencia americana em Santo Domingo, em 1511. Termina, em todo caso, com o aperfeiçoamento do sistema de administração fiscal durante o reinado de Felipe III.

Um terceiro período é caracterizado pelo embate entre a burocracia imperial e a sociedade criolla e pela penetração desta na burocracia imperial, empregando mecanismos que, em geral, podem ser classificados dentro do conceito de corrupção, já que se trata de mecanismos que, em sua maioria, são proscritos por lei, porém, finalmente, tolerados pela Coroa. Esta fase abarca mais ou menos o reinado de Felipe IV. Depois, começa a fase que denominamos de formação de proto-Estados, pela influência ascendente de uma sociedade criolla cada vez mais consciente de si mesma. Esta fase dura até o começo das lutas de independência, porém, pode ser subdividida em três fases menores. A primeira época vai mais ou menos de Carlos II até o fim da guerra de sucessão espanhola, caracterizada pela permanência irrefutável da influência criolla. A esta segue a primeira fase do reformismo bourbônico, tímido, mais voltado a melhorar o sistema de comunicações e comércio espanhol com a América, na qual surge e se aplica à América o conceito de "colônias", no sentido moderno da palavra. O reinado de Felipe V conclui essa fase. Com Fernando VI, inicia a fase do reformismo bourbônico radical, durante a qual são cortados certos mecanismos centrais que asseguravam a influência criolla, como a supressão do sistema de benefícios de empregos, o começo das medidas de abolição do arrendamento de rendas reais e o intento de regulamentação dos repartimientos de mercadorias, que efetuavam os corregidores e alcaldes mayores com os índios de sua jurisdição, sem esquecer a nomeação de superintendentes da Real Hacienda que recaiu nas pessoas dos vicereis. Essas medidas são todas tomadas entre 1746 e 1751 e constituem um ataque fundamental ao poder criollo na América. Esse reformismo radical tem continuidade com Carlos III, ainda que se lhe introduzam novos matizes, como o de formar com a América um "corpo unido da nação"; prossegue logo com uma série de disputas em torno ao conceito de "colônias" e perdura com breves interrupções na época de Carlos IV, interrupções motivadas pela política internacional e a oposição criolla, até o começo do processo de emancipação em 1808.

A cronologia proposta é bastante global, porém, indica, a nosso entender, as principais fases do processo. Uma análise mais minuciosa permitiria seguramente descobrir toda uma série de subfases ou períodos. Contudo, para o nosso propósito, não parece oportuno insistir neste aspecto que, inclusive, os especialistas da história do processo institucional na América hispânica considerariam discutível.

\section{MODELOS DE ORGANIZAÇÃO POLÍTICA}


De certo modo, a primeira fase do desenvolvimento político autônomo começa quando Bobadilla, o juiz investigador enviado pelos Reis Católicos a La Española, em 1500, prende Cristóvão Colombo e seu irmão e os envia presos à Península. Neste momento termina a fase da empresa "portuguesa" da expansão hispânica, imposta por Colombo, e que foi classificada como colonização comercial. Antes de se tentar aplicar um novo modelo político à América, durante o breve lapso de seu governo interino, Bobadilla, que não havia recebido ordens concretas, deixou aos povoadores que ficaram livres na ilha que buscassem o seu proveito como quisessem. Então, ocorre um fenômeno muito interessante que, apesar de a historiografia tê-lo enfocado pouco, parece haver influído na política posterior da Coroa. A maior parte dos espanhóis se distribui ao longo da ilha e começa a viver entre os índios, segundo relata Las Casas muito drasticamente. Fazem-se servir pelos índios, entram em uniões com mulheres relacionadas com o cacique da região, descuidam seu vestir, fazem-se levar em hamacas, constituem, de forma grotesca, uma espécie de "corte": nomeiam índios e índias para funções cortesãs de serviço (mordomos, copeiros, camareiras etc.). Aprendem rapidamente o idioma indígena e pouco cuidam de seus deveres religiosos; em resumo, começam a "barbarizarem-se".

Frente a isso, a Corte reage em $1502 \mathrm{com}$ o envio do comendador Ovando como governador, com instruções que contêm o novo esquema político: os espanhóis têm que viver em vilas e cidades e os índios devem ser reunidos em pueblos próximos aos assentamentos espanhóis. São impostas normas religiosas e de trabalho tanto aos índios quanto aos colonos peninsulares, e, a um só tempo, se estabelecem regras para proteger os índios e cristianizá-los. As Ordenanzas de Ovando já contêm os princípios da política de colonização que a partir de então será seguida e que inicia a colonização de assentamentos e povoação. Uma linha política que encontrará sua expressão máxima nas famosas ordenanzas de pacificação e povoação das Índias de 1571. A eleição de governador entre os membros das ordens militares é muito significativa; quer dizer que se começa a aplicação na América das normas de repovoamento das terras reconquistadas do Islã na Espanha e, ainda mais, da política que na Península se levou a cabo na reconquista de Extremadura e de Andaluzia. O intervalo que precede ao governo de Ovando dá a entender que esta política não só pretende integrar os índios a um modelo de sociedade à castelhana, mas que as medidas prescritas, especialmente o caráter urbano da colonização, também pretendem ser um mecanismo para impor uma disciplina social aos colonos espanhóis que vão à América, com o objetivo de evitar que se reproduzam fenômenos de "barbarização" como os ocorridos no tempo de Bobadilla. Considerando a política posterior da Coroa a partir deste episódio, deve-se dizer que os empenhos por impor a autoridade da Coroa significam também e sempre um esforço para manter em vigência o modelo social castelhano, contra a tentação de uma mestiçagem biológica, social e cultural excessiva. Assim também se explica a tentativa posterior de impedir a mestiçagem mediante a política de segregação de índios e espanhóis e mediante a constituição das "duas Repúblicas", a dos índios e a dos espanhóis, que começa a ser posta em prática em meados do século XVI. Deste modo, será possível explicar não só as medidas de discriminação dos mestiços, mas também o receio frente aos criollos, que se começa a notar posteriormente. Na política da Coroa, prima-se na sequência pela forma de impor, dentro do possível, os modelos metropolitanos na América. Não é pura casualidade que a colonização se desenvolva nesta época renascentista, que tanto empenho põe 
em resgatar a herança da Antiguidade grega e romana ${ }^{33}$.

Porém, ao recorrer às tradições da Reconquista, aparecerá com maior pujança na América o modelo senhorial, ao qual recorrerão na sequência não só Diego Colombo e seus partidários - quando o filho do almirante for restabelecido como vice-rei e governador em 1507-1508 -, mas também os chefes das hostes posteriores de conquistadores, os encomenderos surgidos da conquista e também, de certo modo, as elites criollas posteriores. Isso criará um tensionamento político entre Diego Colombo, que muito claramente recorre a este modelo, e Fernando, o Católico. A tensão entre os herdeiros de Colombo e a Coroa deixa ver de modo muito claro que, já nesses primeiros tempos, a Coroa não estava disposta a aceitar na América a parte senhorial da herança baixo-medieval da Reconquista.

O que talvez se tenha de valorar mais neste contexto é o fato de que, por iniciativa de Diego Colombo, conquistou-se a ilha de Cuba com um pessoal seguramente bastante partidário seu. E que, mais tarde, saiu de Cuba a hoste de Hernán Cortés para a conquista do México, isto é, a região

\footnotetext{
${ }^{33} \mathrm{Cf}$. para o precedente o que lhe segue: ARRATIZ MÁRQUEZ, Luis. Repartimientos y encomiendas en la Isla Española. In: El repartimiento de Albuquerque de 1514. Madrid, 1991. Don Diego Colón. Tomo 1. Madrid,

1982. PONS, Frank Moya. Después de Colón. Trabajo, sociedad y política en la economía de oro. Madrid, 1986. GARCÍA REGUEIRO, O. Oro y población. In: La producción aurífera cubana: 1518-1542. Madrid, 1994. PIETSCHMANN, Horst. La evangelización y la política de poblamiento y urbanización en Hispanoamérica. In: Pontificia Comissio pro America Latina (Ed.). Historia de la evangelización de América. Trayectoria, identidad y esperanza de un continente. Ciudad del Vaticano, 1992, p. 489 et seq. PIETSCHMANN, Horst, La resistencia española al imperio: Las Indias en los años iniciales del reinado de Carlos V. In: Universidad Complutense de Madrid (Ed.). Estudios de Historia del derecho Europeo. Homenaje al Prof. G. Martínez Diez. 20 vol. Madrid, 1994, p. 13-30. PIETSCHMANN, Horst. Los problemas políticos indianos, el humanismo político y la autoridad imperial. In: Carlos V y la quiebra del humanismo político en Europa (15301558), Sociedad Estatal para la Conmemoración de los
}

do continente onde estas tradições senhoriais quiçá tiveram maior impacto. Claro que se deve atribuir este fato também à organização "senhorial" do Império asteca, de modo que tanto as tradições dos conquistadores como as dos conquistados (ou diríamos "enseñoreados", se pensamos nos resultados da investigação etnohistórica recente?) ali se complementavam melhor que em qualquer outro lugar ${ }^{34}$.

O novo conceito de colonização que começou a ser introduzido com o envio de Nicolás de Ovando, ao insistir paralelamente no caráter urbano da colonização, introduziu também na América hispânica nascente $\mathrm{o}$ princípio da representação. Representação em seguida reclamada por cidades e vilas que iam sendo fundadas: primeiro, em representações individuais de cidades e vilas da ilha; e, logo, em momentos de crise, por meio de juntas de cidades com aspirações de formar cortes. Assim, pode-se observar já em abril de 1518 uma reunião dos procuradores de 11 cidades, vilas e lugares de $L a$ Española, na qual se discutiram assuntos de interesse comum. Essa reunião, qualificada por alguns historiadores como reunião de cortes e por outros como "ayuntamiento general" 35 , estava

Centenarios de Felipe II e Carlos V. $4^{\circ}$ vol. Madrid, 2001, p. 48-70. Já havendo me ocupado em muitos trabalhos desta problemática da época colonial, na continuação do texto prescindo de referir a ampla bibliografia sobre estes temas citada nos trabalhos referidos; na sequência, restrinjo-me só aos títulos necessários para ilustrar os contextos referidos. 34 Além do citado na nota anterior, cf. GIMÉNEZ FERNÁNDEZ, Manuel. Bartolomé de Las Casas. 2 vols. Sevilla, 1958-1960. RAMOS, Demetrio. Hernán Cortés. Mentalidad y propósitos. Madrid, 1992. Quanto à investigação etno-histórica, cf. PIETSCHMANN, Horst. Sprache, Mission und Kolonisation oder die Entstehung neuer kultureller Identit: das Beispiel Mexiko. In: Internationale Schulbuchforschung. Zeitschrift des GeorgEckert-Instituts, Braunschweing, a. 15, n. 4, 1993, p. 435449, onde constam amplas citações; PIETSCHMANN, Horst. Estado y conquistadores: las capitulaciones. In: Historia, Santiago, vol. 22, 1987, p. 249 et seq.

${ }^{35}$ GIMÉNEZ FERNÁNDEZ, Manuel. Op. cit., nota n. 34, vol. 2, pp. 147 ss. GIMÉNEZ FERNÁNDEZ, Manuel. Las cortes de La Española de 1518. In: Anales de la Universidad Hispalense, vol. XV, n. 2, 1954, p. 47 et seq. 
fortemente influenciada pelos interesses divergentes dos grupos políticos existentes na ilha: o colombinista e o fernandino (dos partidários de Fernando, o Católico). Contudo, conseguem elaborar um "caderno de petições" similar ao que costumavam apresentar as Cortes castelhanas. É interessante, entretanto, ressaltar que os dois grupos políticos advogavam a partir de modelos políticos distintos. Os colombinistas sublinhavam mais a autonomia da ilha e as aspirações a um "desenvolvimento" próprio que incluía os índios, aos quais se pretendia proteger como vassalos presumidos, com uma espécie de paternalismo senhorial, enquanto que os fernandinistas representavam mais os interesses econômico-comerciais metropolitanos. Estes últimos queriam promover mais a exploração das jazidas auríferas da ilha e utilizar os índios como mão de obra produtiva. Isso também os primeiros, de certa forma, queriam; porém, em razão de seu desejo de desenvolvimento autônomo, insistiam mais em fazê-los trabalhar na produção agrícola ao modo dos vassalos europeus, e, portanto, insistiam mais em sua conservação.

É bem verdade que naquele momento o número de índios já se havia reduzido, de tal maneira que havia de se pensar também em uma reestruturação da economia da ilha, porque estava começando, além de minguar consideravelmente a produção aurífera, a emigração de muitos colonos a Cuba. Foi nesses anos que finalmente ali se impôs o modelo das plantações, propagado também pelos padres jerônimos, que haviam sido enviados à ilha para estudar o problema indígena. É uma coincidência bastante significativa que um ano depois daquela junta de cidades, Carlos V concedera o primeiro assento de negros a um de seus cortesãos. Parece que outra vez se recorre ao modelo que os portugueses haviam desenvolvido em sua colonização das ilhas atlânticas, justo no momento em que a ilha de La Española começava a despovoar-se de índios e colonos europeus. Esse modelo de colonização, no qual dominam as plantações e a mão de obra dependente ou escrava, generaliza-se mais tarde no Caribe e conduzirá a sociedades escravagistas que desenvolverão uma afinidade muito maior com a metrópole que as sociedades coloniais que começaram a surgir com a empresa de Hernán Cortés, iniciada em 1519.

Considerando-se esses fenômenos mais de perto e em fases cronológicas mais curtas, vê-se corroborada de novo a antiga tese de que o Caribe foi o laboratório no qual os castelhanos ensaiaram as diferentes alternativas de colonização. E se deve concluir desde já que ali surgiram os dois tipos de colonização que iriam desenvolver-se no futuro e que se distinguiriam também em suas expressões políticas ao longo da época colonial.

Antes de nos ocuparmos com o segundo modelo de colonização, que, em última medida, pode ser reduzido ao modelo que Diego Colombo em vão tentou desenvolver, deve-se olhar o Istmo do Panamá, em que se realizou, desde 1512-1513, o primeiro assentamento firme de Castela no continente americano, denominado Castilla del Oro, porém, aparentemente, sem o prefixo de Reino de que aparecerá mais tarde. Ali, no início, Vasco Núñez de Balboa havia tentado uma colonização pacífica, tratando de atrair os índios, projeto que foi logo destruído por Pedrarias Dávila, que, inclusive, destituiu Balboa e chegou, ao final, a sentenciá-lo à morte e a executá-lo.

Parece-me que, também neste caso, permanece subjacente o mesmo conflito que, em La Española, levou à remoção - mais elegante, certamente - de Diego Colombo, ainda que a questão não tenha sido estudada desde esta perspectiva. Contudo, os distintos modos de proceder de Balboa e de Pedrarias fazem pensar que também aqui se tratava de um conflito entre, de um lado, uma colonização baseada em uma integração pacífica dos índios em uma sociedade autônoma e distinta da castelhana e, de outro, o modelo comercial-exploratório representado por Pedrarias. A consideração das estruturas que se 
desenvolveram posteriormente no Istmo corrobora esta interpretação. Em todo caso, há que se admitir que, tanto nas ilhas como posteriormente no Istmo, nunca se encontra um criollismo tão acentuado como nas outras regiões, a não ser como um fenômeno tardio.

Da empresa de Hernán Cortés - em muitos aspectos uma continuação da linha Diego Colombo/Cuba/Nova Espanha, e, inclusive, um desenvolvimento ascendente dessa linha - surgirá finalmente o primeiro "Reino" indiscutível na América. Cortés se encontrou com um império indígena e não com tribos soltas de pouco desenvolvimento político. Reduzindo-se a empresa de Cortés ao essencial, pode-se sintetizála desta maneira: a pequena tropa encontrou cada vez mais grupos étnicos cujos senhores estavam descontentes com o domínio asteca e dispostos a aliarem-se contra o Império, e finalmente conquistou a capital asteca e tomou seus dirigentes como prisioneiros, apoiado por muitíssimos senhores índios que com sua gente de guerra ajudaram aos europeus. Cortés, conservando praticamente intactas as estruturas hierárquicas do Império, ocupou com os seus o lugar dos dirigentes astecas, os quais logo tentou integrar, dentro do possível, neste sistema hierárquico de vassalagem como uma elite de mando de segunda categoria. Graças à manutenção das estruturas senhoriais indígenas, dispôs dos recursos do Império e com a introdução do regime da encomienda, em sentido contrário ao expressamente determinado pela Coroa, estabeleceu uma elite de mando espanhola que esperava que viesse a sustentá-lo no futuro.

Ao denominar a terra conquistada de Reino de Nueva España, recorre ao conceito do que se entendia por "Reino" na época estamental, isto é, a uma sociedade estamental, hierarquizada

\footnotetext{
${ }^{36}$ Para o conjunto do desenvolvimento durante o século XVI, cf. PIETSCHMANN, Horst. El Estado y su evolución al principio de la colonización española de América. México, 1989; com respeito às alusões de Hernán Cortés ao Império, cf. FRANKL, Viktor. Die Begriffe des
}

por um sistema de vassalagem que reconhece como superior o "rei". Porém, este fica vinculado pelos direitos representativos de seus vassalos, que têm o direito de serem ouvidos e de ver remunerados os serviços que lhe prestam, seja na paz como na guerra. O rei é, nesta linha de pensamento, pouco mais que um "primus inter pares" em relação a seus nobres, juiz supremo e caudillo superior na guerra, enquanto que seus vassalos estão dotados de uma ampla gama de foros que os imunizam frente a aspirações arbitrárias de poder por parte do rei. O princípio da representação, que a nobreza reclama individualmente e os homens comuns o fazem por meio de suas organizações municipais, determina em todo caso a relação entre o rei e o reino. De modo que a denominação Reino de Nueva España contém todo um programa político no que toca aos dois substantivos que integra, como também com respeito ao adjetivo que forma parte do nome da nova entidade política. Cortés, inclusive, timidamente dá um passo a mais quando refere a Carlos V, que poderia aspirar ao título de "Imperador" com maior direito desde a Nova Espanha, que como "imperador dos Romanos", assim aludindo seguramente ao fato de que em um caso seria um Império de conquista, enquanto, no outro, baseava-se "somente" em uma eleição ${ }^{36}$.

A partir de então vão surgindo no continente, como consequência das conquistas, toda uma série de "reinos". A fundação de reinos surge de dois focos de colonização: Cuba e o Istmo do Panamá, que não ostentavam este título. De Cuba surge o Reino de Nova Espanha e deste os Reinos de Nueva Galicia, de Guatemala, de Nueva Vizcaya e de Nuevo León, enquanto que do Istmo do Panamá surgem os reinos do Peru, Chile, Quito e Nueva Granada. Sabemos pouco, até o momento, dos critérios que definiam a condição

mexikanischen Kaisertums und der Weltmonarchie in den 'cartas de relación' des Hernán Cortés. In: Saeculum, vol. XIII, n. 1, p. 01 et seq. (edição castelhana em: Cuadernos Hispanoamericanos, n. 165, 1963, p. 443 et seq.). 
de uma região conquistada como reino ou como província. A situação pré-hispânica poderia ser alegada nos casos da Nueva España, Peru e Quito, porém, ela não explica outros casos como os de Nuevo León, Nueva Vizcaya, Nueva Galicia e Chile. Tampouco se pode alegar que as "províncias" surgem de conquistas que têm sua origem em reinos previamente estabelecidos. O único que têm em comum os reinos que se estabelecem no continente é o fato de que nenhum deles é fundado por uma expedição procedente diretamente da Península, até onde se pode hoje julgar. Pode-se alegar, em troca, que toda empresa saída de Castela produz somente "províncias", porém, também surgem províncias em terras conquistadas desde reinos americanos, como, por exemplo, Yucatán, Nicarágua, Tucumán e algumas outras. Acaso a criação de um reino significa maiores aspirações de autonomia? Parece muito provável, porém a falta de investigações sobre o tema impede afirmá-lo categoricamente.

O que, sim, parece certo é que a Coroa não adota os termos reino e províncias em sua designação jurídica das novas possessões, mas que se empenha em seguir utilizando o termo Indias, Islas e Tierras Firmes del Mar Océano durante muito tempo. Só muito mais tarde adota também o termo Reinos de las Indias. Empenhase, ao invés, em dotar as novas possessões de um aparato burocrático que a pouco e pouco vem a deslocar desde o cume os poderes emanados do regime das capitulações e conquistas; deslocando, primeiro, o poder do caudillo de uma hoste conquistadora ao instaurar audiencias com faculdades mais ou menos extensas de governo; logo, os vice-reis e o sistema de presidentes, capitanes generales e governadores. Em uma segunda fase, também são reduzidos os poderes políticos dos encomenderos ao criar-se o sistema de corregidores e alcaldes mayores. Prestou-se pouca atenção ao fato de que, também entre os índios, tenta-se desmantelar, ou ao menos reduzir, o poder dos senhores índios. Isso acontece na Nova Espanha com a introdução do sistema municipal, que converte os senhorios indígenas em "repúblicas" ou "comunidades" com uma constituição municipal dentro da qual os caciques se convertem, primeiro, em regidores $\mathrm{e}$ gobernadores propietarios, porém, mais tarde, em 1565, Felipe II suprime os direitos "feudais" desses ao determinar que os índios não exerçam vassalagem sobre seus índios ${ }^{37}$.

No Peru, ambos os fenômenos acontecem um pouco mais tarde durante o mando do vice-rei Toledo. $\mathrm{O}$ importante do processo de estabelecimento do sistema burocrático na América, que se deve a Carlos V e a Felipe II, é que as jurisdições dos diferentes cargos apenas respeitam a divisão em reinos e províncias que surgiu da conquista. Os vice-reinados integram vários reinos e a jurisdição das audiencias às vezes desborda de suas fronteiras. Ainda não se investigou a fundo até que ponto $o$ estabelecimento do aparato burocrático levou em conta jurisdições previamente estabelecidas e especialmente o sistema de reinos e províncias.

Neste contexto é também muito interessante que na primeira descrição geral das Índias, elaborada por Juan López de Velasco, praticamente não se fala de reinos, mas se divide a descrição por distritos de bispados, audiencias etc. E, mais, no caso de Nova Espanha, por exemplo, fala-se sempre expressamente da "provincia de Nueva España". Se um cosmógrafo-cronista do Consejo de Indias e estreito colaborador do grande legislador indiano e visitador do Consejo de Indias, Juan de Ovando, insiste em aplicar essa terminologia, a suspeita é mais que fundada de que naquela época a Coroa

\footnotetext{
${ }^{37}$ Real Cédula de Felipe II, Monzón, 27 de septiembre de 1563. Real Academia de la Historia, Colección Salazar y Castro, n. 22, fl. 106.
} 
estava pouco inclinada a fazer sua a terminologia criada pelos conquistadores ${ }^{38}$.

Se levarmos em conta que já desde o final do reinado de Carlos V começavam a aumentar consideravelmente as queixas que os primeiros conquistadores e seus descendentes enviam sobre a falta de recompensa real a seus méritos, sobre sua perda de cargos, encomiendas etc., resulta evidente que a Coroa estava ao que parece firmemente decidida a terminar com todos os vestígios senhoriais e com a representação organizada em forma de cortes, juntas de cidades etc. Conseguiu-o com um mecanismo simples: insistir no direito individual de representar ao rei, admitindo não só as representações diretas à Coroa de todos os níveis da nova administração civil e eclesiástica, mas também de todas as corporações e até indivíduos na América. Ainda que esse aspecto não esteja investigado a fundo, parece que a tendência é muito clara e se reflete em um grande volume de cartas ao rei de toda classe de organismos e indivíduos, que se canalizava através do Conselho de Índias.

Segundo os estudos de história econômica e social, a época que vai mais ou menos de 15601570 até 1620 pode qualificar-se como a fase de formação da sociedade e da economia coloniais. Os conquistadores, seus descendentes e os novos imigrantes iniciam a aquisição de terras e a organização de uma agricultura ao estilo europeu. Formam-se agremiações de artesãos e se instrumentalizam os mecanismos de comércio interior. Porém, tal processo se relacionou só parcialmente com a ampla legislação metropolitana e americana no particular, pois os

38 Cf. LÓPEZ DE VELASCO, Juan. Geografía y descripción universal de las Indias. Edição de Don Marcos Jiménez de la Espada, Biblioteca de Autores Españoles, tomo CCXLVIII. Madrid, 1971.

${ }^{39}$ As referências à bibliografia jurídica se encontram, ao menos quanto à maioria dos estudos apresentados nos congressos do Instituto Internacional de Historia del Derecho Indiano, em HERA, Alberdo de la; BARRERO, Ana María; MARTÍNEZ DE CODES, Rosa María. La historia del derecho indiano. Aportaciones del Instituto historiadores da economia prestavam pouca atenção à legislação correspondente e os historiadores do direito se limitavam a estudá-la sem indagar o impacto de tal legislação no funcionamento real da economia ${ }^{39}$. O certo é que dito processo vai acompanhado da formação de elites e oligarquias coloniais, processo no qual a Coroa participa ativamente com a introdução do sistema de ofícios vendáveis e renunciáveis, que converte muitos cargos municipais, e parte também da administração real, em venais. Oferecia-se, assim, às novas elites econômicas a possibilidade de se estabelecerem em postos de importância local, consolidando sua posição social. Repete-se o mesmo mecanismo que, já no final do século anterior, haviam utilizado os Reis Católicos para consolidar sua autoridade em Castela, freando assim consideravelmente durante bastante tempo a pujança do sistema representativo. Esse mecanismo seguramente contribuiu de maneira eficaz para que, também na época de Felipe II, fosse possível estabelecer um sistema de administração fiscal e se pudesse introduzir o sistema impositivo castelhano ${ }^{40}$.

A consolidação econômica e social das sociedades coloniais começa pouco a pouco a minar o poder da Coroa, porque o novo aparato administrativo, pelo afã de lucro e ascensão social, entra cada vez mais em alianças com as oligarquias coloniais que controlam os recursos econômicos de modo crescente. Uma brecha começa a abrir-se entre os interesses criollos e os interesses metropolitanos, agudizada pelas avultadas necessidades financeiras da metrópole e o início da penetração estrangeira, penetração esta

Internacional de Historia del Derecho Indiano a la bibliografía jurídica americanista. Madrid, 1989. Quanto à historiografia econômica e social, remeto às referências bibliográficas incluídas no Balance de la historiografía sobre Iberoamérica (1945-1988). IV Conversaciones Internacionales de Historia. Pamplona, 1989.

${ }^{40}$ Cf. PIETSCHMANN, Horst. Die staatliche Organisation des kolonialen Iberoamerika. Stuttgart, 1980; no qual se encontra sintetizado, com bibliografia, o desenvolvimento político que aqui se menciona. 
não só clandestina no comércio legal, mas também direta pela intervenção de forças navais dos inimigos da Espanha.

Quando os mecanismos tradicionais do controle burocrático - visitas e residências, estabelecimento das administrações especiais por meio do sistema comissarial - já não produzem os resultados desejados, a Coroa busca, nos princípios do reinado de Felipe IV, alcançar uma maior coesão entre as distintas partes do Império e obter sua maior colaboração nos esforços bélicos da Espanha. Esse novo esforço não produz os resultados desejados, e, inclusive, conduz a um estrepitoso fracasso em Nova Espanha, com o levante contra o vice-rei Gelves ${ }^{41}$. Parece que a partir de então a Coroa ensaia novos métodos políticos na América. Recorre-se ao sistema de "donativos graciosos" exigidos aos americanos, e se começa a beneficiar praticamente a todos os cargos administrativos, contrariando abertamente a própria política de assegurar o funcionamento desinteressado e honesto da burocracia ${ }^{42}$. E não só se propagam muitos mecanismos de corrupção, mas, com o sistema de benefícios de cargos, os criollos conseguem penetrar massivamente no aparato burocrático e manipular as instituições em benefício de seus interesses ${ }^{43}$. O criollismo se consolida, assim, na esfera econômica e social, e também na política. Não poderá surpreender, portanto, que esse processo se veja acompanhado de manifestações culturais, já muito claras, de uma identidade própria.

Paralelamente, na América hispânica, as regiões começam a se articular mais em virtude do dinamismo da economia, das concentrações

\footnotetext{
${ }^{41}$ Cf., por exemplo, ISRAEL, Jonathan. Race, Class and Politics in Colonial Mexico 1610-1670. Oxford, 1975.

${ }^{42} \mathrm{Cf}$. PIETSCHMANN, Horst. Burocracia y corrupción en Hispanoamérica colonial. Una aproximación tentativa. In: Nova America, Turim, vol. 5, 1982, p. 11 et seq.

Antecedentes españoles e hispanoamericanos de las intendencias. In: Anuario de Estudios Americanos, Sevilla, vol. XL, 1983, p. 359 et seq.

${ }^{43}$ Cf., por exemplo, BURKHOLDER, M. A.; CHANDLER, D. S. From Impotence to Authority. The Spanish Crown and
}

demográficas, institucionais e de poder e de outros fatores geopolíticos. As novas articulações do espaço colonial apenas parcialmente, e quando fosse $\mathrm{o}$ caso, respondiam às estruturas governamentais do aparato imperial estabelecido durante o século XVI. Basta pensar nos desvios da prata alto-peruana via Tucumán a Buenos Aires e no intenso comércio e contrabando que se estabeleceu em toda essa rota, e que em muito contribuiu ao auge progressivo da região do Rio da Prata, que finalmente levou à criação do vicereinado de mesmo nome. O lento crescimento de regiões como Chile, Venezuela e a capitania geral de Guatemala é outro exemplo. Para essas regiões, excluídas do comércio direto com a metrópole pelo sistema de frotas e galeões, o contrabando era o recurso principal, o qual lhes facilitava um desenvolvimento autônomo, que, por sua vez, contribuía a uma maior autonomia administrativa e, por consequência, também política. Ao mesmo tempo, dá-se um processo inverso: por diferentes causas - sejam geopolíticas, econômicas etc. - determinadas regiões, dotadas, inclusive, de aparato burocrático próprio, entram na órbita de centros mais poderosos que conseguem impor política e economicamente sua autoridade e poder. Tal é o caso, por exemplo, de Nueva Galicia e os demais reinos do norte da Nova Espanha, que dependem da audiencia de Guadalajara.

Esse conjunto de desenvolvimentos contraditórios, que até o momento só se estudou parcialmente na dimensão econômica, porém muito pouco na político-administrativa, em realidade é o início do processo que denominamos

the American Audiencias, 1687-1808. Columbia, 1977; e outros estudos sobre o mesmo tema dos mesmos autores para o caso das audiencias. Toda uma série de outros estudos analisa essa prática em relação a outros cargos, cf. PIETSCHMANN, Horst. Burocracia y corrupción en Hispanoamérica colonial. Una aproximación tentativa. In: Nova America, Turim, vol. 5, 1982, nota n. 42, com referências bibliográficas a outros estudos. 
de fase de formação de proto-Estados. Tem início durante o século XVII com o aumento progressivo do poder criollo e a lenta desarticulação do sistema imperial metropolitano que, no final das contas, durante o século XVIII, obriga a Coroa a reorganizar o sistema políticoadministrativo e espacial com a criação de novos vice-reinados, governos, audiencias e, também, das intendencias.

As reformas do século XVIII são, em grande media, a consequência ou a resposta tardia a desenvolvimentos prévios que se produziram mais bem contra a vontade da metrópole, em momentos de debilidade da Coroa, frente ao processo de desarticulação imperial que ocorre não só na América, mas também nas possessões europeias. É precisamente a perspectiva global do Império hispânico para a segunda metade do século XVII que permite caracterizar esse processo de desintegração imperial como um processo de surgimento de novas entidades políticas que adquirem um maior grau de autonomia e influíram na formação de novos Estados independentes. O processo inicia com a rebelião dos Países Baixos, continua no século XVII com as rebeliões catalã e portuguesa, e, depois, com o desmembramento das partes europeias do Império na Paz de Utrecht. A América espanhola segue esse processo com um atraso bastante compreensível, porém, o segue, e, inclusive, com um grau maior de autonomia, já que faltam as fortes ingerências estrangeiras que, no caso da Europa, contribuíram poderosamente para a aceleração do processo desintegrador. É, pois, lícito falar desde a perspectiva latinoamericana de um processo de formação de protoEstados, quando se pensa no sistema de Estados independentes que nos princípios do século XIX surgirão das lutas independentistas.

\footnotetext{
${ }^{44}$ ENCINAS, Diego de. Cedulario indiano. 4 vols. Madrid, 1946 (edição fac-símile). SÁNCHEZ BELLA, Ismael. (Org.). Recopilación de las Indias por Antonio de León Pinelo. 3 vols. México, 1992. Recopilación de leyes de los reinos de las Indias, mandadas imprimir, y publicar por la
}

Nesse contexto, convém recordar outro fenômeno pouco estudado, porém bastante claro: o reconhecimento do status de reinos às possessões hispânicas na América no momento de maior debilidade da Coroa. Isso se deduz de uma rápida olhada pelo processo de recopilação e sistematização da legislação indiana. A primeira tentativa ao final do século XVI, realizada por Diego de Encinas, é denominada Cedulario Indiano; nos anos vinte do século XVII, Antonio de León Pinelo redige sua Recopilación de Indias, e, em 1680-1681, finalmente é publicada a Recopilación de los Reynos de las Indias ${ }^{44}$. É pouco provável que tais denominações sejam uma casualidade em uma época na qual o estilo cortesão e os conceitos jurídicos são tão importantes na vida política e administrativa. Deve-se aprofundar no estudo desse problema, tão importante quanto ao conceito que a Coroa tem de suas possessões americanas. Isso é tanto mais importante quando se pensa que nos princípios da época bourbônica já começa a se difundir na Península o conceito de "colônias". E ainda que esse conceito não ingresse na legislação, muitos altos funcionários nos reinados de Felipe V a Carlos III o compartilham. A reação criolla na segunda metade do século XVIII, até os inícios do movimento emancipador, acentuará de novo o conceito de "reino", que, ao menos nos anos noventa do século XVIII, uma parte dos altos mandos metropolitanos aceita novamente. Porém, do mesmo modo que os dirigentes peninsulares não estão de acordo em seus conceitos sobre a América, tampouco os criollos constituem um bloco homogêneo de convicções políticas, pois as ideias da Ilustração e as reformas de Carlos III foram dividindo-os. Ainda que a historiografia recente só o reconheça de passagem, e sem prestar muita importância ao fato ${ }^{45}$, este parece certo,

Magestad Católica del Rey Carlos II (...). 4 vols. Madrid, 1973 (edição fac-símile).

${ }^{45}$ Essa problemática foi analisada com maior amplitude em: PIETSCHMANN, Horst. Protoliberalismo, reformas borbónicas y revolución: La Nueva España en el último 
quando se considera detidamente os debates políticos de ambos os lados do Atlântico.

O reformismo de Carlos III é, certamente, o último grande esforço da Coroa para reestruturar todo o conjunto americano. As opiniões da historiografia recente sobre o impacto dessas reformas são, entretanto, bastante contraditórias. As afirmações dos estudiosos vão desde as daqueles que consideram que tiveram pouco impacto até as daqueles que pensam que contribuíram para desarticular definitivamente o vínculo entre a metrópole e suas possessões americanas, preparando, assim, o processo emancipador. Para poder opinar sobre esse tema é necessário primeiro definir as metas principais que as reformas perseguiam. Frequentemente, reduz-se esse aspecto ao interesse da Coroa em aumentar seu controle sobre a América e alcançar maiores ingressos fiscais e ganhos comerciais. No entanto, a realidade é mais complexa, e a análise detalhada das distintas medidas permite descobrir muitas facetas mais de impacto das reformas, segundo os níveis sociais, econômicos e geográficos considerados. As reformas não são nem tão categoricamente anticriollas, como se quis afirmar, nem tão abertamente em favor da metrópole, como também se disse. Amplos setores criollos se beneficiaram, por exemplo, pela introdução do livre comércio, especialmente nos âmbitos provinciais. E, com a introdução das intendencias, beneficiaram-se os grupos locais distantes dos centros burocráticos e econômicos coloniais de poder. Além do mais, o aumento dos ingressos fiscais acompanha o aumento do gasto fiscal na América.

Em todo caso, combinando-se os significados das distintas medidas, o mais provável é que se trate da introdução de um novo conceito de Estado, que dispõe de uma burocracia

tercio del siglo XVIII. In: ZORAIDA VÁZQUEZ, Josefina. (Coord.). Interpretaciones del siglo XVIII mexicano. El impacto de las reformas borbónicas. México, 1992, p. 27 et seq. Mais detalhadamente, insiste-se nesses problemas em um estudo sobre o impacto das reformas de Carlos III na mais eficaz e que tende a romper o poder de grupos oligárquicos e a dinamizar a sociedade. $\mathrm{O}$ impacto foi diferente segundo as regiões e em atenção a suas distintas realidades, porém, em geral, foi considerável, pois contribuiu, em suma, para desestabilizar as estruturas econômicas, sociais e políticas prévias e a introduzir novos padrões culturais. Além disso, a série de rebeliões originadas pelas reformas revela que o conjunto de medidas introduzidas afetou os interesses existentes de modo muito diverso. Ainda que na década de 1790 a Coroa tenha tratado de suavizar o impacto produzido pelas reformas precedentes, só o conseguiu em parte, pois a situação na Espanha não permite a aplicação de uma política clara e conduzida com certa continuidade.

As reformas, claramente, contribuem para precipitar o conjunto de reinos e províncias americanas nas guerras de Independência. Porém, essas não podem ser interpretadas partindo de um modelo bipolar - aqui, o americano; lá, o peninsular. A realidade é mais complexa e, às vezes, apresenta o caráter de guerras civis nas quais se lutava por interesses regionais, políticos, econômicos etc. São momentos nos quais se ajustam contas, acumuladas desde há muito, entre peninsulares e criollos, entre criollos provinciais e criollos metropolitanos, entre elites europeuamericanas e castas, entre senhores e dependentes ou escravos etc. Dos reinos iniciais, muitos poucos conseguiram converter-se em Estados independentes sem grandes mudanças: Chile e Quito; Nova Espanha e Nova Granada se estenderam mais além de suas fronteiras iniciais; Guatemala e Peru foram recortados e os reinos ao norte da Nova Espanha foram absorvidos por esta. Os motores do processo foram, entretanto, duas províncias: Venezuela e Buenos Aires, movidas por criollos - porém, com qual identidade? -

Nova Espanha, segundo um documento coetâneo, a ser publicado no ano de 1995 em Jahrbuch für Geschichte von Staat, Wirstschaft und Gesellschaft Lateinamerikas, no idioma castelhano. 
inspirados pelas ideias da Europa revolucionária, enquanto que as elites criollas dos antigos reinos conservaram até bastante tarde as ideias baixomedievais da representação.

\section{REFERÊNCIAS}

ANNINO, Antonio. et al. (Org.). America Latina: Dallo Stato Coloniale allo Stato Nazione, 17501940. 2 vols. Milão, 1987.

ARNOLD, Linda J. Bureaucracy and Bureaucrats in Mexico City, 1742-1835. Tucson, 1988.

ARRATIZ MÁRQUEZ, Luis. Don Diego Colón. Tomo 1. Madrid, 1982.

. Repartimientos y encomiendas en la Isla Española. In: El repartimiento de Albuquerque de 1514. Madrid, 1991.

BAKEWELL, Peter J. Silver Mining and Society in Colonial Mexico, Zacatecas, 1546-1700. Cambridge, 1971.

BORAH, Woodrow. Early Colonial Trade and Navigation between Mexico and Peru. Berkeley, 1954.

. New Spain's Century of Depression. Berkeley, 1951.

. Silk Raising in Colonial Mexico. Berkeley, 1943.

; COOK, Sherbume F. Price Trends of Some Basic Commodities in Central Mexico, 1531-1570.

BRADING, David A. Miners and Merchants in Bourbon Mexico, 1763-1810. Cambridge, 1971.

1993.

Orbe indiano. De la monarquía católica a la República criolla, 1492-1867. México: FCE,

. The First America. The Spanish Monarchy, Créole, Patriots and the Liberal State, 1492-1867. Cambridge: Cambridge University Press, 1985.

BURKHOLDER, Mark A.; CHANDLER, D. S. De la impotencia a la autoridad. La corona española y las audiencias en América, 1687-1808. México, 1984.

. From Impotence to Authority. The Spanish Crown and the American Audiencias, 1687-1808. Columbia, 1977.

CALVO, Thomas. Círculos de poder en la Guadalajara del siglo XVIII y la Nueva Galicia en los siglos XVI y XVII. México, 1989.

CARMAGNANI, Marcello. [Sem título]. In: Handbuch der Geschichte Lateinamerikas. Stuttgart, 1994, no prelo.

. El regreso de los dioses. El proceso de reconstitución de la identidad étnica en Oaxaca. Siglos XVIII y XIX. México, 1988. 
CHEVALIER, François. La formation de grands domaines au Mexique: terre et sociètè aux XVI ${ }^{e}$-XVII siècles.

CHAUNU, Pierre; CHAUNU, Huguette. Séville et l'Atlantique, 1504-1650. 8 tomos em 11 volumes. Paris, 1955-1958.

DEHOUVE, Danièle. Quand les banquiers étaient des Saints. 450 ans de l'histoire économique et sociale d'une province indienne du Mexique. Paris, 1990.

EISENSTADT, S. N. The Political Systems of Empires. New York, 1963.

ENCINAS, Diego de. Cedulario indiano. 4 vols. Madrid, 1945-1946.

FISHER, John; KUETHE, Allan J.; McFARLANE, Anthony. (Eds.). Reform and Insurrection in Bourbon New Granada and Peru. Baton Rouge; London, 1990.

FLORESCANO, Enrique. (Coord.). Atlas histórico de México. 1983.

FRANKL, Viktor. Die Begriffe des mexikanischen Kaisertums und der Weltmonarchie in den 'cartas de relación' des Hernán Cortés. In: Saeculum, vol. XIII, n. 1.

. [Sem título]. Cuadernos Hispanoamericanos, n. 165, 1963.

GARCÍA GALLO, Alfonso. Los orígenes españoles de las instituciones americanas: estudios de derecho indiano. Madrid, 1987.

GARCÍA REGUEIRO, O. Oro y población. In: La producción aurífera cubana: 1518-1542. Madrid, 1994.

GERHARD, Peter. Geografía histórica de la Nueva España, 1519-1821. México, 1986.

GIMÉNEZ FERNÁNDEZ, Manuel. Bartolomé de Las Casas. 2 vols. Sevilla, 1958-1960.

1954.

. Las cortes de La Española de 1518. In: Anales de la Universidad Hispalense, vol. XV, n. 2,

HAMNETT, Brian R. Politics and Trade in Southern México, 1750-1821. Cambridge, 1971.

HANKE, Lewis. Los virreyes españoles en América durante el gobierno de la Casa de Austria. Perú. 7 vols. Madrid, 1978-1980.

HERA, Alberto de la; BARRERO, Ana María; MARTÍNEZ DE CODES, Rosa María. La historia del derecho indiano. Aportaciones del Instituto Internacional de Historia del Derecho Indiano a la bibliografía jurídica americanista. Madrid, 1989.

ISRAEL, Jonathan. Race, Class and Politics in Colonial Mexico 1610-1670. Oxford, 1975.

KAHLE, Günter; PIETSCHMANN, Horst. (Eds.). Lateinamerika. Entdeckung, Eroberung, Kolonisation, Gesammelte Aufsätze von Richard Konetzke. Colonia-Viena, 1983. 
KONETZKE, Richard. Colección de documentos para la historia de a formación social de Hispanoamérica, 1493-1810. 3 volumes em 5 tomos. Madrid, 1953-1962.

. América Latina II. La época colonial. Historia universal. Madrid: Siglo XXI, 1971.

. Süd und Mittelamerika I. Die Indianerkulturen Altamerikas und die spanisch-portugiesche Kolonialherrschaft. Fischer Welteschichte. Vol. 22. Frankfurt, 1965.

La Colección Documental del Bicentenario de la Revolución Emancipadora de Túpac Amaru. 5 vols. Lima, 1980-1982.

LAFAYE, Jacques. Quetzalcóatl et Guadalupe. La formation de la conscience nationale au Mexique, 1631-1813. Paris, 1974.

1977.

. Quetzalcóatl y Guadalupe. La formación de la conciencia nacional en México. México: FCE,

LAVALLÉ, Bemard. Recherches sur l'apparition de la conscience créole dans la vice-royauté du Pérou: l'antagonisme hispano-créole dans les ordres religieux (XVI $-X V I I^{e}$ siècle). 2 vols. Lille, 1982.

. Las promesas ambiguas. Ensayos sobre el criollismo colonial en los Andes. Lima, 1993.

. Le Marquis et le Marchand. Les luttes de pouvoir au Cuzco (1700-1730). Paris, 1987.

LOHMANN VILLENA, Guillermo. Los ministros de la Audiencia de Lima en el reinado de los Borbones, 1700-1821. Sevilla, 1974.

LUJÁN MUÑOZ, Jorge. Los escribanos en las Indias Occidentales. México, 1982.

LOMBARDI, Cathryn L; LOMBARDI, John V. Latin American History. A Teaching Atlas. Madison, 1983.

LÓPEZ DE VELASCO, Juan. Geografía y descripción universal de las Indias. Edição de Don Marcos Jiménez de la Espada, Biblioteca de Autores Españoles, tomo CCXLVIII. Madrid, 1971.

MARAVALL, José Antonio. Estado moderno y mentalidad social. Siglos XV a XVII. 2 vols. Madrid, 1972.

MEISSNER, Jochen. Eine Elite im Umbruch. Der Stadtrat von Mexiko zwischen kolonialer Ordnung und unabhägigem Staat. Stuttgart, 1993.

MORALES PADRÓN, Francisco. Atlas histórico cultural de América. 2 vols. Las Palmas de Gran Canaria, 1988.

MURO ROMERO, Fernando. La reforma del pacto colonial en Indias. Notas sobre instituciones de gobierno y sociedad en el siglo XVII. In: Jahrbuch für Geschichte von Staat, Wirstchaft und Gesellschaft lateinamerikas. Colonia-Viena, vol. 19, 1982.

OUVENEEL, Arij; MILLER, Simon. (Eds.). The Indian Community of Colonial Mexico. Fifteen Essays on Land Tenure, Corporate Organization, Ideology and Village Politics. Amsterdam, 1990. 
PHELAN, J. L. The Kingdom of Quito in the Seventeenth Century. Bureaucratic Politics in the Spanish Empire. Madison, 1967.

PIETSCHMANN, Horst. Alcaldes Mayores, Corregidores und Subdelegados. Zum Problem, der Distriktsbeamtenschaft im Vizekönigreich Neuspanien. In: Jahrbuch für Geschichte von Staat, Wirstchaft und Gesellschaft lateinamerikas. Colonia-Viena, vol. 9, 1972.

. Antecedentes españoles e hispano-americanos de las Intendencias. In: Memorias del Cuarto Congreso Venezolano de Historia, 27 de octubre- $1^{\mathrm{er}}$ de noviembre de 1980, 3 vols., Caracas, 1983.

. Antecedentes españoles e hispanoamericanos de las intendencias. In: Anuario de Estudios Americanos, Sevilla, vol. XL, 1983.

Burocracia y corrupción en Hispanoamérica colonial. Una aproximación tentativa. In: Nova Americana, Turín, n. 5, 1982.

. Die Einführung des Intendantensystems in Neu-Spanien im Rahmen der allgemeinen Verwaltungsreform der spanischen Monarchie im 18. Jahrhundert. Colonia-Viena, 1972.

. Die staatliche Organisation des kolonialen Iberoamerika. Stuttgart, 1980.

. El comercio de repartimientos de los alcaldes mayores y corregidores en la región de PueblaTlaxcala en el siglo XVIII. Simposio Hispanoamericano de Indigenismo Histórico, Terceras Jomadas Americanistas de la Universidad de Valladolid, Valladolid, 1977.

. El Estado y su evolución al principio de la colonización española de América. México: FCE, 1989.

Estado colonial y mentalidad social: el ejercicio del poder frente a distintos sistemas de valores, siglo XVIII. In: ANNINO, Antonio. et al. (Org.). America Latina: Dallo Stato Coloniale allo Stato Nazione, 1750-1940. $2^{\circ}$ vol. Milán, 1987.

. Estado y conquistadores: las capitulaciones. In: Historia, Santiago, vol. 22, 1987.

La evangelización y la política de poblamiento y urbanización en Hispanoamérica. In: Pontificia Comissio pro America Latina (Ed.). Historia de la evangelización de América. Trayectoria, identidad y esperanza de un continente. Ciudad del Vaticano, 1992.

. La resistencia española al imperio: Las Indias en los años iniciales del reinado de Carlos V. In: Universidad Complutense de Madrid (Ed.). Estudios de Historia del derecho Europeo. Homenaje al Prof. G. Martínez Diez. 2º vol. Madrid, 1994.

. Los problemas políticos indianos, el humanismo político y la autoridad imperial. In: Carlos $V$ y la quiebra del humanismo político en Europa (1530-1558), Sociedad Estatal para la Conmemoración de los Centenarios de Felipe II e Carlos V. 4º vol. Madrid, 2001.

. Protoliberalismo, reformas borbónicas y revolución: La Nueva España en el último tercio del siglo XVIII. In: ZORAIDA VÁZQUEZ, Josefina. (Coord.). Interpretaciones del siglo XVIII mexicano. El impacto de las reformas borbónicas. México, 1992. 
. Sprache, Mission und Kolonisation oder die Entstehung neuer kultureller Identit: das Beispiel

Mexiko. In: Internationale Schulbuchforschung. Zeitschrift des Georg-Eckert-Instituts, Braunschweing, a. 15, n. 4, 1993.

. Staat und staatliche Entwicklung am Beginn der spanischen Kolonisation Amerikas. Münster, 1980.

PONS, Frank Moya. Después de Colón. Trabajo, sociedad y política en la economía de oro. Madrid, 1986.

RAMÍREZ, Susan E. Land Tenure and the Economics of Power in Colonial Peru. Albuquerque, Nuevo México, 1986.

RAMOS, Demetrio; et al. El Consejo de las Indias en el siglo XVI. Valladolid, 1970.

. Hernán Cortés. Mentalidad y propósitos. Madrid, 1992.

Real Cédula de Felipe II, Monzón, 27 de septiembre de 1563. Real Academia de la Historia, Colección Salazar y Castro, n. 22, fl. 106.

Recopilación de leyes de los reynos de las Indias. 3 vols. Madrid, 1943.

Recopilación de leyes de los reinos de las Indias, mandadas imprimir, y publicar por la Magestad Católica del Rey Carlos II (....). 4 vols. Madrid, 1973 (edição fac-símile).

RIKLES, Carlos Malamud. [Sem título]. In: Revista de Occidente, n. 116, jan. 1991.

RODRÍGUEZ-MOÑINO, Antonio. Memoriales presentados al Real Consejo de Indias (1626-1630). Madrid: 1953.

SAGUIER, Eduardo. La corrupción administrativa como mecanismo de acumulación y engendrador de una burguesía nativa. In: Anuario de Estudios Americanos, Sevilla, vol. XLVI, 1989.

SAINT-LU, André. Condition coloniale et conscience créole au Guatemala. Paris, 1970.

SÁNCHEZ BELLA, Ismael. Las visitas generales en la América española (siglos XVI-XVII). In: . Derecho indiano. Estudios. 2 vols. Pamplona, 1991.

. (Org.). Recopilación de las Indias por Antonio de León Pinelo. 3 vols. México, 1992.

SÁNCHEZ ALBORNOZ, Nicolás. La población de América Latina. Desde los tiempos precolombinos al año 2000. Madrid, 1973.

SANDOVAL, Fernando B. La industria del azúcar en Nueva España. México, 1951.

SCHÄFER, Ernesto. El Consejo Real y Supremo de las Indias. Su historia, organización y labor administrativa hasta la terminación de la Casa de Austria. 2 vols. Sevilla, 1935-1947. 
SARFATTI, Magali. Spanish Bureaucratic Patrimonialism in America. Politics of Modernization Series, n. 1, Institute of International Studies, University of California. Berkeley, 1966.

SERRERA, Ramón. Tráfico terrestre y red vial en las Indias españolas. Madrid, 1992.

VÁZQUEZ DE PRADA VALLEJO, Valentín; OLÀBARRI GORTÁZAR, Ignacio. (Org.). Balance de la historiografía sobre Iberoamérica. Actas de las IV Conversaciones Internacionales de Historia. Centro de Investigaciones de Historia Moderna y Contemporánea, Universidad de Navarra, Pamplona, 10-12 marzo 1988. Pamplona, 1989.

VOLLMER, Günter. Mexikanische Regionalbezeichnungen. In: Jarbuch... lateinamerikas, 16 Jahrhunfert, vol. 9, 1972.

ZORRAQUÍN BECÚ, Ricardo. Estudios de historia del derecho. 3 vols. Buenos Aires, 1988-1992.

Recebido em: $31 / 12 / 2016$

Aceito em: 31/12/2016 
